\title{
Ett röjningsröseområde i Farstorp - odling, begravning och ritual
}

\author{
MARIA PETERSSON
}

Petersson, M. 2020. A clearance cairn site at Farstorp - cultivation, burial and ritual. AmS-Varia 61, 115-137, Stavanger, ISSN 0332-6306, ISBN 978-82-7760-187-8

\begin{abstract}
This paper problematises the categories grave and clearance cairn, based on source-material from Farstorp, Småland. A central point of departure for the analysis is landuse in a long-term perspective. Parts of a clearance-cairn site, comprising clearance-cairns, graves and constructions similar to graves although less well-built, were excavated. The latter were termed complex cairns. Exterior elements were kerbs and surface layers of fire-cracked stones. Interior features resembled cremation layers with fire-cracked stones. Inside and adjacent to these, burnt animal bones and other objects, including intact pots containing food, had been deposited. The main building material was clearance stones, plausibly from surrounding arable land. Features mainly date to Late Roman Iron Age and Migration Period. Fire-cracked stones and burnt animal bones are interpreted as waste from ritual meals, consumed during spring and autumn farm work. Depositions of grinding stones support the assumption that fertility of the land was an important ritual theme. Participants of these meals might be members of the household that held the land rights. A few human bones were deposited in each grave, possibly from deceased members of the owner family who might be expected to act in favour of their living descendants, to enhance fertility in general. Such deposits may also have demonstrated and consolidated land rights.
\end{abstract}

Maria Petersson, The Archaeologists, National Historical Museums, Roxengatan 7, S-582 73 LINKÖPING. SWEDEN. E-mail: maria.petersson@arkeologerna.com

Keywords: Early Iron Age, fossil fields, clearance cairns, complex cairns, graves, depositions, ritual

\section{Inledning}

Vid Farstorp utanför Nässjö i Småland aktualiserades frågan om grav eller röjningsröse på ett påtagligt vis (Fig. 1). Förundersökningen visade att av cirka 150 röjningsrösen inom undersökningsområdet, hade ett femtiotal stensättningsliknande drag (Sjölin, 2013a). Lämningarna låg samlade på ett sätt som påminde om ett gravfält, de var välbyggda med välvd form, jämt stenmaterial med skärvsten i ytan, kantkedja och i enstaka fall mittgrop. Flera delundersöktes och innehöll keramik, brända ben och liknande. När vi undersökte en skadad lämning med kantkedja, en inre skärvstenspackning och ett mindre brandlager med keramik och brända ben, antog vi att tolkningen av de gravlika anläggningarna var löst, även om anläggningarnas utseende, som ett mellanting mellan grav och röjningsröse, fortfarande var ett problem. Den osteologiska analysen visade emellertid att benen i de delundersökta anläggningarna kom från tamdjur, medan mänskliga kvarlevor saknades. Tolkningen av röjningsrösena med speciella drag var därmed fortfarande en öppen fråga, även om de stensättningslika dragen antydde att det, förutom anknytningen till jordbruket, fanns en koppling till den rituella sfären och en datering till äldre järnålder.

I arbetet med slutundersökningen försökte vi närma oss problemet från ett annat håll. Ett brett landskapsperspektiv kombinerades med ett detaljerat handlings- och aktörsperspektiv. Undersökningarna syftade inte till att kategorisera lämningarna utifrån bevarade formelement utan istället att besvara frågan: Vilka handlingar har människor utfört på denna plats? För att underlätta diskussionen av anläggningarna med stensättningsliknande drag, har dessa i texten benämnats dem komplexa stenrösen, en i första hand operationell benämning. 


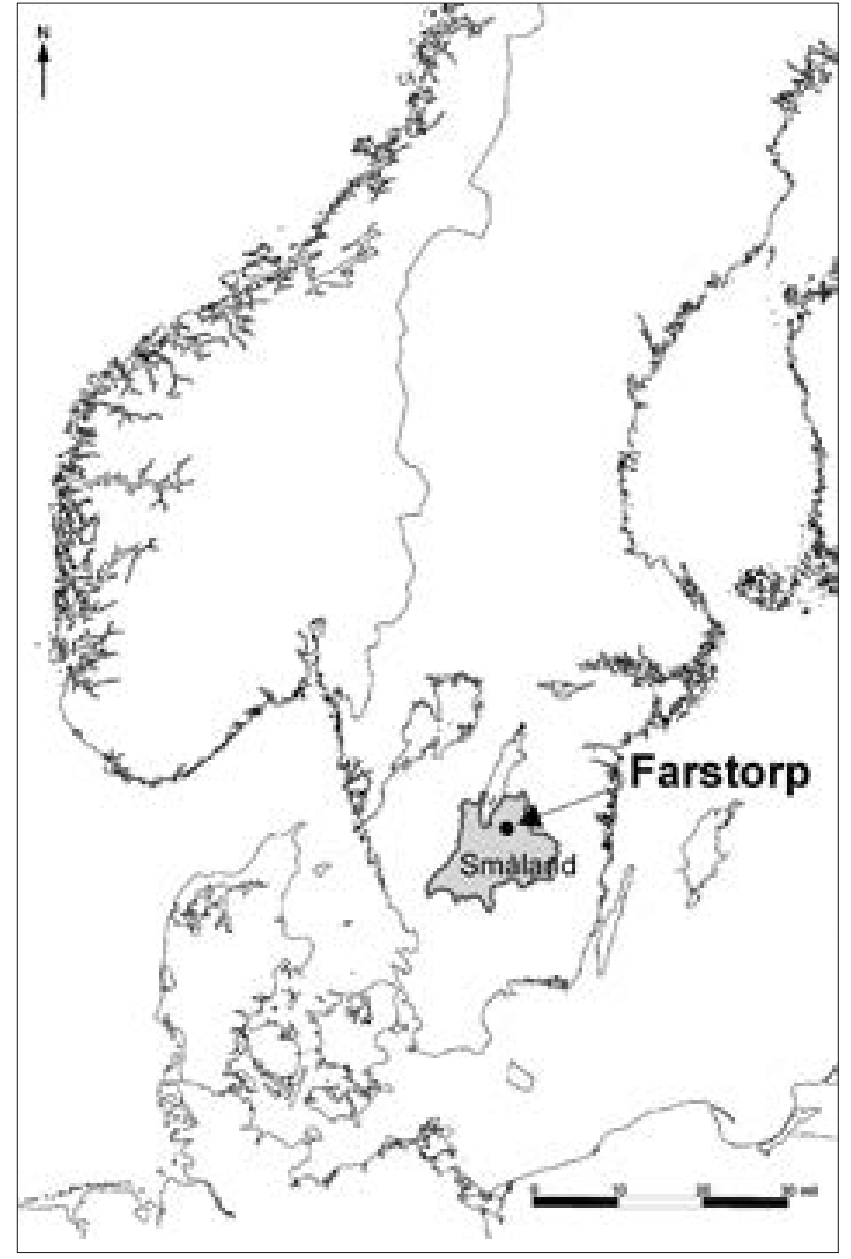

Fig. I. Farstorp i Småland. Grafik: Johan Stenvall, RAÄ. Fig. I. Farstorp in the county of Småland, Sweden. Graphics: Johan Stenvall, RÄ̈.

I artikeln sätts anläggningarna huvudsakligen in i ett svenskt forskningssammanhang. Såväl lämningstyper som diskuterade problemområden har dock sina motsvarigheter inom norskt område (t.ex. Holm, 2004; Mjærum, 2012)

\section{Forskningsbakgrund}

Röjningsröseområden är en karaktärsfornlämning för Småländska höglandet. Fornlämningarna upptar vanligen en yta av mellan två och fem hektar, men kan omfatta hundratals hektar. Inom röjningsröseområdena ligger röjningsrösena ofta tätt och ytorna mellan rösena har tydlig karaktär av odlingsmark även om terrasskanter och -hak är mera sällsynta. Rösena anses vara resultatet av stenröjning i samband med odling och slåtter nämns ibland som bidragande faktor (Pedersen \& Widgren, 1998; Lagerås, 2000, 2013; Berglund \& Börjesson, 2002; Mascher, 2002; Widgren, 2003; Vestbö-Franzén, 2004; Häggström, 2005; Skoglund, 2005, 2006; Åstrand, 2007; Alering, 2010; Engman, Lorenzon \& Vestbö-Franzén, 2015; Andersson \& Widgren, 2016).
Områdena representerar oftast ett stort tidsdjup och ett första ianspråktagande under bronsålder förekommer (Alering, 2010, s. 32; Lagerås, 2013, s. 269). Starka expansionsperioder för markanvändning har här varit romersk järnålder, äldre medeltid och 1500-tal. Under dessa perioder har röjningsröseområdena vuxit i storlek och bruket av dem intensifierats. Den s.k. folkvandringstida krisen samt den medeltida agrarkrisen representerar två tydliga perioder med avmattning och övergivande av områdena.

Tolkningen av markanvändningen inom röjningsröseområdena under bronsålder och äldre järnålder har följt två skilda spår. Leif Gren menade att röjningsröseområdena har tillkommit som ett resultat av skottskogsbruk med upprepat svedjebruk, där markanvändningen var cyklisk med ett par års odling och därefter en 20-50 år lång period av bete och gradvis igenväxning (Gren, 1989, s. 87ff). Per Lagerås menade istället att åkermarken under romersk järnålder varit mobil inom röjningsröseområdena, men att åkrarna bytt läge mera sällan, kanske med varje ny generation brukare (Lagerås, 2000). Lagerås' modell innebär att åkrarna varit gödslade samt att de legat nära gårdsbebyggelsen, medan övriga delar av röjningsröseområdet fungerat som betesmark. I ett längre tidsperspektiv indikerar båda modellerna att betesdrift varit den dominerande näringen inom röjningsröseområdena.

Det var först i början av 1980-talet, som röjningsröseområden uppmärksammades som en ny fornlämningskategori (Gren, 1989; Norman, 1989, s. 97ff; Gren, 1991). Man noterade då att det regelbundet förekom gravar från framför allt äldre järnålder i områdena. När områdena efterhand kom att beröras av arkeologiska undersökningar, blev det tydligt att de lämningskategorier som vid fornminnesinventeringen definierats utifrån visuella kriterier, inte utan problem kunde överföras på lämningar som undersökts genom utgrävning (jfr. Svanberg, 2000; Kraft, 2005; Häggström, 2007; Hansson, 2008). Det fanns å ena sidan röjningsrösen som innehöll både föremål och människoben, å andra sidan gravar som saknade alla spår av mänskliga kvarlevor (Nilsson, 1987, s. 104; Jansson, 1999). Det fanns också välbyggda anläggningar, ibland med inre konstruktioner och fynd, som inte riktigt hörde hemma i någon av kategorierna. Ibland hade de även drag gemensamma med skärvstenshögar. Den klassificering som används i till exempel Kulturmiljöregistret (Riksantikvarieämbetet), är alltså inte alltid relevant i förhållande till de konkreta lämningarna, men inte heller till en förhistorisk idévärld. Detta är problematiskt och får stora konsekvenser för den antikvariska processen. 
De förhistoriska gravar som saknar mänskliga kvarlevor, förklaras ibland i termer av formationsprocesser, det vill säga att det har funnits ben men att dessa har brutits ner så att spår saknas (Häggström, 2007, s. 74; jfr. Schiffer, 1987). En annan förklaring är att anläggningarna aldrig innehållit mänskliga kvarlevor utan uppförts som ett slags minnesmärken över personer som dött på annan plats, s.k. kenotafer (Björkhager, 1992). Funktioner för gravar utan mänskliga kvarlevor som altare, dödshus, kremeringsplatser har också föreslagits (Kaliff, 1999; Häggström, 2007, s. 74), liksom att de fungerat som revirmarkeringar och att det då var mindre viktigt att de innehöll mänskliga kvarlevor (Nilsson, 1987, s. 104). I nyare forskning har gravfält och gravar även diskuterats utifrån uppfattningar om transformationsprocesser, minne och tid (Röst, 2016).

Flera forskare har särskilt uppmärksammat att det finns anläggningar som liknar gravar, men är något mindre välbyggda (Svanberg, 2000; Kraft, 2005; Häggström, 2007; Hansson, 2008). De kan ha inre konstruktionsdetaljer och innehålla fynd, men saknar mänskliga kvarlevor. Anders Kraft menar att dessa är «en möjlig diffus form av grav» som i högre grad sammanhänger med jordbruket genom att de ursprungliga gravöverbyggnaderna byggts på med röjningssten i ett rituellt sammanhang (Kraft, 2005, s. 110f). Fredrik Svanberg framhåller problemen med att «passa in alla röse- och stensättningsliknande anläggningar i de två enkla kategorierna grav eller odlingsröse» (Svanberg, 2000, s. 124f; jfr. också Hansson, 2008, s. 164).

Skärvstenshögar förekommer också i röjningsröseområden och tolkningsdiskussionerna har många likheter med diskussionerna kring kategorierna gravar och röjningsrösen. Skärvstenhögar som kategori är mångtydig och en gemensam förklaring till deras uppkomst torde saknas (Rentzhog, 1967; Hyenstrand, 1968; Lundqvist, 1991; Kaliff, 1997). Det förekommer ofta konstruktionsmässiga likheter med samtida gravar från brons- och järnålder som yttre och inre kantkedja samt mittblock och skärvstenshögar kan också innehålla gravgömmor (Hyenstrand, 1984; Rundkvist, 1994, s. 82). Vanliga fynd är keramik, handkvarnar, stenyxor, brynen, avslag, bronsföremål, slagg och vävtyngder. Skärvstenshögar har tolkats som avfallshögar, men även kopplats till ölbryggning och bronsgjutning (Gustawsson, 1949; Nylén, 1958; Wigren, 1987). De har tolkats som symboliskt uttryck för markinnehav (Lundqvist, 1991). På gravfält har de satts i samband med en fruktbarhetskult som varit nära förbunden med dödskulten, och vidare tolkats som fundament för likbål (Bellander, 1938; Nylén, 1958). Anders Kaliff framhåller också att «det [är] rimligt att anta att skärvstenhögarna är platser där ett antal aktiviteter kombinerats» (Kaliff, 1994, s. 121). Lars Lundqvist framhåller att kategorierna gravar och avfallshögar inte nödvändigtvis är relevanta för studiet av skärvstenshögar - även andra kategorier kan ha funnits i det förhistoriska samhället (Lundqvist, 1991).

\section{Teoretiska och metodiska utgångspunkter}

Vid undersökningen av röjningsröseområdet i Farstorp valde vi att förflytta fokus från ett kategoriserande av lämningar som tog utgångspunkt i karaktären på det som bevarats till idag. Istället inriktades undersökningen mot de handlingar som fanns representerade på platsen som helhet, liksom i enskilda anläggningar. Ansatsen innebar att två tematiska områden kom i fokus:

- markanvändning i ett långt tidsperspektiv

- en problematisering av begreppen grav och röjningsröse.

En teoretisk grundval utgjorde den moderna landskapsforskningen som till sin natur är tvärvetenskaplig (jfr. Ashmore \& Knapp, 1999, Berg, 2003). Landskapsperspektivet kombineras med fördel med det långa tidsperspektivet, där särskilt mer trögrörliga strukturer lämnar spår i landskapet (Carelli, 2001, s. 13). Ett komplement till det långa tidsperspektivet är ett aktörs- eller handlingsperspektiv med fokus på enskilda handlingar, vilka även dessa har lämnat spår i landskapet (Bell, 1992, s. 197ff).

De tematiska problemområdena, i kombination med den teoretiska grundvalen styrde val av undersökningsmetoder. En av de bärande metoderna var maskinavbaning av stora, sammanhängande områden av fossil åkermark, vilket gav översikt och sammanhang (jfr. Petersson, 1999). För stensättningar, komplexa stenrösen och ett urval av röjningsrösena användes kontextuell undersökningsmetod (eng. single-context), något som var helt avgörande för resultaten (Harris, 1979). Metoden innebär att de stratigrafiska enheterna avlägsnas var för sig, i tur och ordning, med den yngsta först. Fokus vänds därmed mot den serie handlingar som resulterat i t.ex. ett röjningsröse och kategoriserandet av lämningen som helhet tonas ned. En tredje faktor som väsentligt bidragit till resultaten var att ett brett spektrum av naturvetenskapliga metoder användes, enligt en speciellt anpassad analysstrategi.

Här bör också framhållas betydelsen av den fältarkeologiska processen, med fortlöpande tolkningar på 


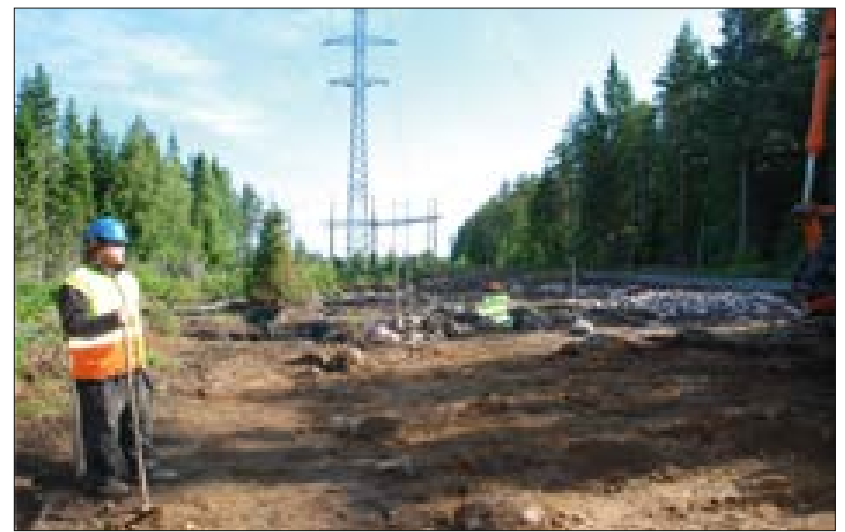

Fig 2. Omfattande maskinavbaningar av fossila åkerytor kombinerades med detaljerade undersökningar med handredskap av röjningsrösen, gravar och komplexa stenrösen. Foto: Marita Sjölin, RAÄ.

Fig. 2. Extensive machine stripping of fossil fields is combined with detailed hand cleaning of clearance cairns, graves and complex cairns. Photo: Marita Sjölin, RAÄ.

mikro- och makronivå. Den utgör ett samspel av såväl avancerad praktisk som teoretisk kunskap - ibland kallad tyst kunskap - som används av arkeologen vid utgrävningen i skapandet av det arkeologiska källmaterialet (Molander, 1996; jfr. Petersson, 2006, s. 14ff; Botwid, 2016, s. 15ff) (Fig. 2).

\section{Röjningsröseområdet vid Farstorp}

År 2013 undersökte Riksantikvarieämbetet UV Öst i samarbete med Jönköpings läns museum ett cirka $35000 \mathrm{~m}^{2}$ stort utsnitt av ett röjningsröseområde som i sin helhet omfattade uppskattningsvis 450000 $\mathrm{m}^{2}$. Området låg i skogsmark på krönet av en kraftig moränrygg. Det hade vid ett flertal tidigare tillfällen varit föremål för arkeologiska insatser och kunskapen om området hade successivt byggts upp (Sjölin, 2010, 2011; Ajneborn, 2013; Sjölin, 2013a, 2013b; Petersson, 2015). Vid Farstorp har nu sammanlagt tre stensättningar, en omarkerad grav, ett åttiotal röjningsrösen samt ett femtiotal komplexa stenrösen undersökts.

Ett pollendiagram från Staplakärret i kanten av området, har givit en detaljerad bild av markanvändningen (Björkman, 2014). De tidigaste tecknen på mänsklig påverkan var från yngre bronsålder då området sporadiskt använts för skogsbete, en markanvändning som fortsatte till cirka 100 e.Kr., då det fanns spår av kontinuerligt skogsbete. Kring 200 e.Kr. ökade betestrycket i området samtidigt som permanent åkermark hade etablerats. Under yngre romersk järnålder, folkvandringstid och tidig vendeltid blev vegetationen i området gradvis öppnare och mera mosaikartad. Omkring 500 e.Kr. minskade dock först odlingen i området, därefter betet, och området började sedan växa igen. Från och

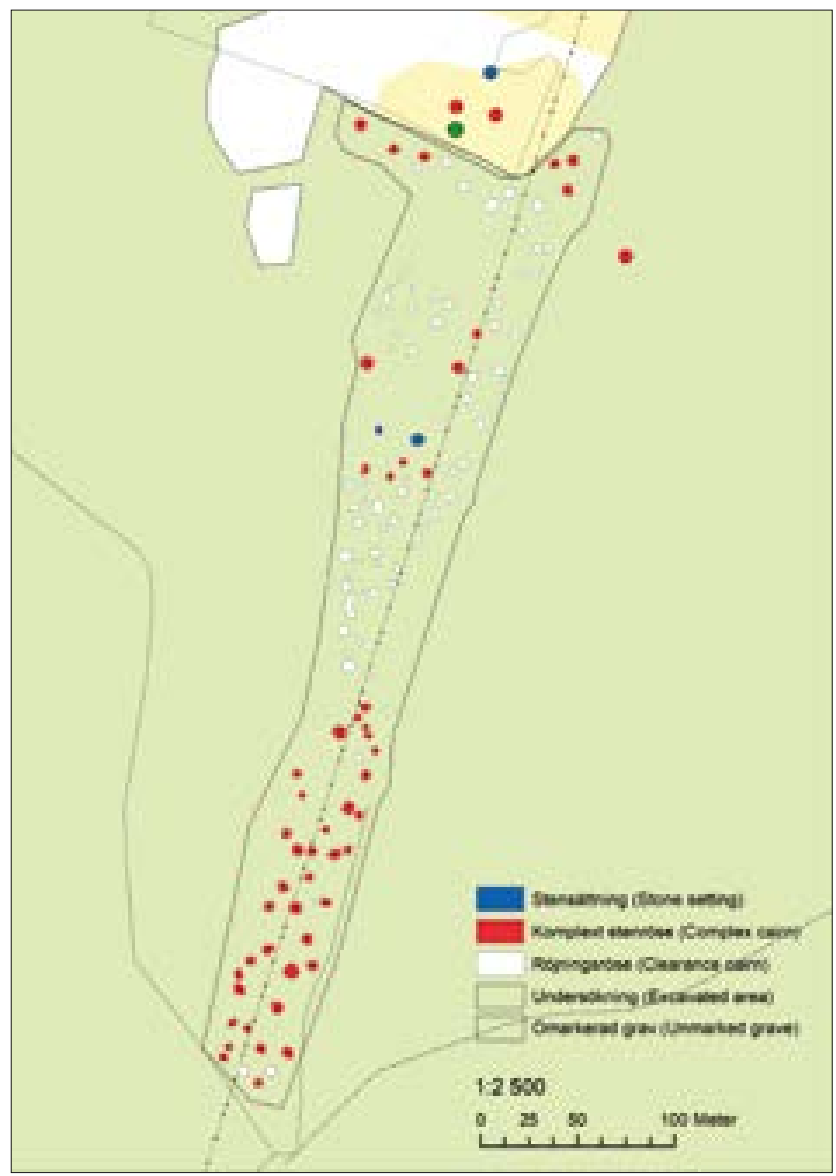

Fig 3. De förhistoriska lämningarna vid Farstorp låg samlade i tre grupper. Grafik: Marita Sjölin, RAÄ.

Fig. 3. The prehistoric sites at Farstorp were situated in three groups. Graphics: Marita Sjölin, RÄ̈.

med cirka 600 e.Kr. var spåren efter odling och bete obetydliga och området hade vuxit igen med björkskog.

På åsryggen inom de hittills undersökta delarna av röjningsröseområdet fanns tre grupper med lämningar från yngre romersk järnålder, folkvandringstid och äldre vendeltid (Fig. 3). Här fanns ett uttalat rumsligt samband mellan förhistoriska röjningsrösen, stensättningar/gravar och komplexa stenrösen.

- I den norra gruppen fanns en rund stensättning med mänskliga kvarlevor, samt en omarkerad brandgrav. Den sistnämnda daterades till yngre romersk järnålder/tidig folkvandringstid. I anslutning till dessa anläggningar fanns nio komplexa stenrösen.

- I den mellersta gruppen fanns två runda stensättningar. Den större, mer välbyggda saknade mänskliga kvarlevor och daterades till äldre vendeltid. I den mindre fanns enstaka brända människoben och anläggningen daterades till folkvandringstid. I anslutning till stensättningarna fanns fem komplexa stenrösen som undersöktes. 
Tabell I. Dateringen av de komplexa stenrösena vid Farstorp grundas på olika metoder. ${ }^{14} \mathrm{C}$-analyser utfördes på träkol och ben från elva komplexa stenrösen. Några kontexter kunde dateras med utgångspunkt i fynd, i kombination med stratigrafiska hänsyn. Resultaten pekar mot att de komplexa stenrösena framför allt har tillkommit under yngre romersk järnålder och folkvandringstid. Möjligheten finns att några även tillkommit under äldsta vendeltid. Tabell: Maria Petersson, RAÄ.

Table I. Dating of complex cairns at Farstorp is based on various methods. Radiocarbon analyses were performed on charcoal and bones from eleven complex cairns. A few contexts could be dated with reference to the finds and their relation to the stratigraphy. The results indicate that complex cairns were mainly constructed during the late Roman Iron Age and Migration period. It is possible that some were constructed during the earliest part of the Vendel period. Table: Maria Petersson, RÄ̈.

\begin{tabular}{|c|c|c|c|c|c|c|}
\hline $\begin{array}{l}\text { Beteckning } \\
\text { Identification }\end{array}$ & Tyр/Tyре & $\begin{array}{l}\mathrm{BP} \\
\mathrm{BP}\end{array}$ & $\begin{array}{l}\text { Std } \\
\text { Std }\end{array}$ & $\begin{array}{l}\text { Labnr } \\
\text { Lab no. }\end{array}$ & Material/Material & $\begin{array}{l}{ }^{14} \mathrm{C} 2 \text { sigma/fynddatering } \\
{ }^{14} \mathrm{C} 2 \text { sigma/dating based on finds }\end{array}$ \\
\hline G120 & Komplext/Complex & 2017 & 77 & Ua-31747 & Bark/Bark & 350 f.Kr-250 e.Kr./350 BC-AD 250 \\
\hline RAÄ 296 & Komplext/Complex & 1766 & 34 & Ua-297II & - & I30-350 e.Kr./AD /30-350 \\
\hline GI58 & Komplext/Complex & 1736 & 33 & Ua-31656 & Björk/Birch & $230-400$ e.Kr./AD 230-400 \\
\hline GI34 & Komplext/Complex & $170 \mid$ & 34 & Ua-3I597 & Björk/Birch & $250-420$ e.Kr./AD 250-420 \\
\hline A2080 & Komplext/Complex & 1670 & 31 & Ua-31017 & Björk/Birch & $320-430$ e.Kr./AD 320-430 \\
\hline RAÄ 288 & Komplext/Complex & 1662 & 30 & Ua-29710 & Björk/Birch & $320-440$ e.Kr./AD 320-440 \\
\hline A5867 & $\begin{array}{l}\text { Omarkerad grav } \\
\text { Unmarked burial }\end{array}$ & 1653 & 32 & Ua-3065I & Björk/Birch & $320-470$ e.Kr./AD 320-470 \\
\hline GI05 & Komplext/Complex & 1627 & 34 & Ua-31646 & Björk/Birch & $340-540$ e.Kr./AD 340-540 \\
\hline GI0I & Komplext/Complex & 1585 & 35 & Ua-31639 & Björk/Birch & $400-560$ e.Kr./AD 400-560 \\
\hline GII5 & Komplext/Complex & 1559 & 30 & Ua-31925 & Ben/Bone & $420-570$ e.Kr./AD 420-570 \\
\hline GI30 & $\begin{array}{l}\text { Stensättning } \\
\text { Stone setting }\end{array}$ & 1550 & 30 & Ua-31926 & Ben/Bone & $420-580$ e.Kr./AD 420-580 \\
\hline GI00 & Komplext/Complex & $|54|$ & 35 & Ua-31640 & Björk/Birch & $420-600$ e.Kr./AD 420-600 \\
\hline GI44 & Komplext/Complex & 1519 & 34 & Ua-31788 & Ben/Bone & $\begin{array}{l}430-620 \text { e.Kr.l} \\
A D 430-620\end{array}$ \\
\hline GI45 & $\begin{array}{l}\text { Stensättning } \\
\text { Stone setting }\end{array}$ & 1466 & 32 & Ua-31789 & Ben/Bone & $\begin{array}{l}545-650 \text { e.Kr. } \\
A D 545-650\end{array}$ \\
\hline GI03 & Komplext/Complex & & & & $\begin{array}{l}\text { Fullrepresenterad keramik } \\
\text { Reconstructable ceramics }\end{array}$ & $\begin{array}{l}\text { Romersk järnålder/Folkvandringstid } \\
\text { Roman Iron Age/Migration Period }\end{array}$ \\
\hline G126 & Komplext/Complex & & & & $\begin{array}{l}\text { Fullrepresenterad keramik } \\
\text { Reconstructable ceramics }\end{array}$ & $\begin{array}{l}\text { Romersk järnålder/Folkvandringstid } \\
\text { Roman Iron Age/Migration Period }\end{array}$ \\
\hline GI4I & Komplext/Complex & & & & $\begin{array}{l}\text { Fullrepresenterad keramik } \\
\text { Reconstructable ceramics }\end{array}$ & $\begin{array}{l}\text { Romersk järnålder/Folkvandringstid } \\
\text { Roman Iron Age/Migration Period }\end{array}$ \\
\hline
\end{tabular}

- I den södra gruppen fanns den största koncentrationen av komplexa stenrösen, 37 stycken, inom undersökningsområdet. Stensättningar och gravar saknades i denna grupp. De komplexa stenrösena var här överlag välbyggda med tydliga yttre formelement. Dateringarna låg i yngre romersk järnålder och folkvandringstid med tyngdpunkt i den senare perioden

Dateringarna visar att aktiviteten i de tre områdena har växlat något över tid men att yngre romersk järnålder och folkvandringstid dominerade. Uppförandet av den större stensättningen i det mellersta området under äldre vendeltid förefaller ha utgjort en slutpunkt (Tabell 1).

\section{Komplexa stenrösen}

Vid Farstorp undersöktes som nämnts ett femtiotal komplexa stenrösen (Sjölin, 2013a, 2013b; Petersson, 2015). Det stora antalet bidrog till att de komplexa stenrösenas särskilda karaktär så tydligt framgick. Antalet bidrog också till att belysa variationsbredden (Tabell 2).

Bland de komplexa stenrösena fanns ett tiotal anläggningar med många och tydliga karaktärsdrag. Ett 
Tabell 2. Tabellen visar undersökta komplexa stenrösen vid Farstorp. Yttre och inre formelement samt fyndmaterial redovisas. Efter Petersson, 2016, Sjölin, 2013a och b. Följande förkortningar används i tabellen: Br. = Brända, Obest. = Obestämda, Ospec. = Ospecificerade. Tabell: Marita Sjölin, RAÄ.

Table 2. The table shows excavated complex cairns at Farstorp. Exterior and interior attributes are presented together with the assemblage of finds. From Petersson 2016, Sjölin 2013a and b. Table: Marita Sjölin, RÄ̈.

\begin{tabular}{|c|c|c|c|c|c|}
\hline $\begin{array}{l}\text { Anl nr } \\
\text { ID no. }\end{array}$ & $\begin{array}{l}\text { Form, mått } \\
\text { Shape, size }\end{array}$ & $\begin{array}{l}\text { Yttre } \\
\text { formelement } \\
\text { Exterior } \\
\text { morphology }\end{array}$ & $\begin{array}{l}\text { Inre } \\
\text { Formelement } \\
\text { Interior morphology }\end{array}$ & $\begin{array}{l}\text { Fyndmaterial } \\
\text { Finds }\end{array}$ & $\begin{array}{l}\text { Osteologiskt material och } \\
\text { makrofossila cerealier } \\
\text { Osteological material and } \\
\text { macrofossil cereals }\end{array}$ \\
\hline 100 & $\begin{array}{l}\text { Oval, } 7 \times 6 \mathrm{~m} \\
\text { Oval, } 7 \times 6 \mathrm{~m}\end{array}$ & $\begin{array}{l}\text { Kantkedja, } \\
\text { skärvstenlager } \\
\text { Kerb, layer of fire- } \\
\text { cracked stones }\end{array}$ & $\begin{array}{l}\text { Skärvstenslager } \\
\text { Layer of fire-cracked } \\
\text { stones }\end{array}$ & $\begin{array}{l}\text { Kvartsavslag, slagg } \\
\text { Quartz flakes, slag }\end{array}$ & $\begin{array}{l}\text { Br. ben, nöt, däggdjur ej människa, } \\
\text { medelstort däggdjur (ej människa) } \\
\text { Burnt bone, cattle; mammal, } \\
\text { non-human; medium sized mammal } \\
\text { (non-human) }\end{array}$ \\
\hline 101 & $\begin{array}{l}\text { Oval, } 6,5 \times 5,6 \mathrm{~m} \\
\text { Oval, } 6.5 \times 5.6 \mathrm{~m}\end{array}$ & $\begin{array}{l}\text { Kantkedja, } \\
\text { skärvstenlager } \\
\text { Kerb, layer of fire- } \\
\text { cracked stones }\end{array}$ & $\begin{array}{l}\text { Skärvstenslager, } \\
\text { skålgrop på sten i } \\
\text { kantkedjan } \\
\text { Layer of fire-cracked } \\
\text { stones, cup mark on } \\
\text { stone in kerb }\end{array}$ & $\begin{array}{l}\text { Malstenslöpare (facetterad), } \\
\text { järnslagg } \\
\text { Hand-stone for quern (faceted); } \\
\text { iron slag }\end{array}$ & $\begin{array}{l}\text { Br. ben, oidentifierbart } \\
\text { Burnt bone, unidentified }\end{array}$ \\
\hline 102 & $\begin{array}{l}\text { Rund, 5,5 m diam } \\
\text { Round, diam } 5.5 \text { m }\end{array}$ & $\begin{array}{l}\text { Kantkedja } \\
\text { Kerb }\end{array}$ & $\begin{array}{l}\text { Skärvstenslager } \\
\text { Layer of fire-cracked } \\
\text { stones }\end{array}$ & & \\
\hline 103 & $\begin{array}{l}\text { Oval, } 6,0 \times 5,0 \mathrm{~m} \\
\text { Oval, } 6.0 \times 5.0 \mathrm{~m}\end{array}$ & $\begin{array}{l}\text { Kantkedja } \\
\text { Kerb }\end{array}$ & $\begin{array}{l}\text { Skärvstenslager } \\
\text { Layer of fire-cracked } \\
\text { stones }\end{array}$ & $\begin{array}{l}\text { I fullrepresenterat kärl } \\
\text { I reconstructable pot }\end{array}$ & \\
\hline 105 & $\begin{array}{l}\text { Rund, } 6,0 \mathrm{~m} \text { diam } \\
\text { Round, diam } 6.0 \mathrm{~m}\end{array}$ & $\begin{array}{l}\text { Kantkedja } \\
\text { Kerb }\end{array}$ & & $\begin{array}{l}\text { Knacksten, slagg, vridkvarn } \\
\text { Hammer stone, slag; rotary quern }\end{array}$ & $\begin{array}{l}\text { Br. ben, trol får } \\
\text { Cerealier, korn, obest. } \\
\text { Burnt bone, probably sheep } \\
\text { Cereals, barley, unidentified }\end{array}$ \\
\hline 108 & $\begin{array}{l}\text { Rund, 5,4 m diam } \\
\text { Round, diam } 5.4 \text { m }\end{array}$ & $\begin{array}{l}\text { Kantkedja } \\
\text { Kerb }\end{array}$ & $\begin{array}{l}\text { Utbyggnad, brandlager } \\
\text { Extension, cremation } \\
\text { layer }\end{array}$ & $\begin{array}{l}\text { Keramikskärvor från } 2 \text { kärl } \\
\text { Potsherds from } 2 \text { vessels }\end{array}$ & \\
\hline 109 & $\begin{array}{l}\text { Rund, 7,6 m diam } \\
\text { Round, diam } 7.6 \text { m }\end{array}$ & $\begin{array}{l}\text { Skärvstenslager } \\
\text { Layer of fire-cracked } \\
\text { stones }\end{array}$ & & & \\
\hline 110 & $\begin{array}{l}\text { Oval, } 6,2 \times 5,3 \mathrm{~m} \\
\text { Oval, } 6.2 \times 5.3 \mathrm{~m}\end{array}$ & $\begin{array}{l}\text { Kantkedja, } \\
\text { skärvstenlager } \\
\text { Kerb, layer of fire- } \\
\text { cracked stones }\end{array}$ & $\begin{array}{l}\text { Stenkista } \\
\text { Stone cist }\end{array}$ & & \\
\hline 111 & $\begin{array}{l}\text { Oval, } 3,6 \times 3,2 \mathrm{~m} \\
\text { Oval, } 3.6 \times 3.2 \mathrm{~m}\end{array}$ & & & $\begin{array}{l}\text { Borrtapp av bergart till } \\
\text { skafthålsyxa } \\
\text { Stone plug from borehole of } \\
\text { shaft-hole axe }\end{array}$ & \\
\hline 112 & $\begin{array}{l}\text { Oval, } 7,0 \times 6,0 \mathrm{~m} \\
\text { Oval, } 7.0 \times 6.0 \mathrm{~m}\end{array}$ & $\begin{array}{l}\text { Kantkedja } \\
\text { Kerb }\end{array}$ & & $\begin{array}{l}\text { Kvartsavslag } \\
\text { Quartz flake }\end{array}$ & \\
\hline 113 & $\begin{array}{l}\text { Rund, } 4,0 \text { m diam } \\
\text { Round, diam } 4.0 \text { m }\end{array}$ & & & $\begin{array}{l}\text { Flintavslag med bruksspår } \\
\text { Flint flake with use-wear striae }\end{array}$ & \\
\hline 115 & $\begin{array}{l}\text { Rund, 5,5 m diam } \\
\text { Round, diam } 5.5 \text { m }\end{array}$ & $\begin{array}{l}\text { Kantkedja } \\
\text { Kerb }\end{array}$ & $\begin{array}{l}\text { Stenkista } \\
\text { Stone cist }\end{array}$ & & $\begin{array}{l}\text { Br. ben, medelstort däggdjur } \\
\text { Cerealier, obest. } \\
\text { Burnt bone, Medium sized mammal } \\
\text { Cereals, unidentified }\end{array}$ \\
\hline 116 & $\begin{array}{l}\text { Rund, 4,5 m diam } \\
\text { Round, diam } 4.5 \mathrm{~m}\end{array}$ & $\begin{array}{l}\text { Kantkedja } \\
\text { Kerb }\end{array}$ & & & \\
\hline 117 & $\begin{array}{l}\text { Rund, } 4,5 \text { m diam } \\
\text { Round, diam } 4.5 \text { m }\end{array}$ & $\begin{array}{l}\text { Kantkedja } \\
\text { Kerb }\end{array}$ & & & \\
\hline 118 & $\begin{array}{l}\text { Oregelbundet } \\
\text { rund, } 4,6 \mathrm{~m} \text { diam } \\
\text { Irregularly round, } \\
\text { diam } 4.6 \mathrm{~m}\end{array}$ & & & $\begin{array}{l}\text { Slagg } \\
\text { Slag }\end{array}$ & \\
\hline 119 & $\begin{array}{l}\text { Rektangulär, } \\
6,5 \times 3,7 \mathrm{~m} \\
\text { Rectangular } \\
6.5 \times 3.7 \mathrm{~m}\end{array}$ & $\begin{array}{l}\text { Kantkedja } \\
\text { Kerb }\end{array}$ & $\begin{array}{l}\text { Skärvstenslager } \\
\text { Layer of fire-cracked } \\
\text { stones }\end{array}$ & $\begin{array}{l}\text { Keramikskärvor från } 3 \text { kärl, } \\
\text { järnfragment } \\
\text { Potsherds from } 3 \text { pots; } \\
\text { Iron fragments }\end{array}$ & $\begin{array}{l}\text { Br. ben, däggdjur } \\
\text { Obr. ben, nöt, däggdjur } \\
\text { Burnt bone, mammal } \\
\text { Unburnt bone, cattle, mammal }\end{array}$ \\
\hline
\end{tabular}




\begin{tabular}{|c|c|c|c|c|c|}
\hline $\begin{array}{l}\text { Anl nr } \\
\text { ID no. }\end{array}$ & $\begin{array}{l}\text { Form, mått } \\
\text { Shape, size }\end{array}$ & $\begin{array}{l}\text { Yttre } \\
\text { formelement } \\
\text { Exterior } \\
\text { morphology }\end{array}$ & $\begin{array}{l}\text { Inre } \\
\text { Formelement } \\
\text { Interior morphology }\end{array}$ & $\begin{array}{l}\text { Fyndmaterial } \\
\text { Finds }\end{array}$ & $\begin{array}{l}\text { Osteologiskt material och } \\
\text { makrofossila cerealier } \\
\text { Osteological material and } \\
\text { macrofossil cereals }\end{array}$ \\
\hline 120 & $\begin{array}{l}\text { Oregebunden, } \\
6,1 \mathrm{~m} \text { diam } \\
\text { Irregular, diam } \\
6.1 \mathrm{~m}\end{array}$ & $\begin{array}{l}\text { Kantkedja, } \\
\text { skärvstenlager } \\
\text { Kerb; } \\
\text { Layer of fire-cracked } \\
\text { stones }\end{array}$ & $\begin{array}{l}\text { Stenkista } \\
\text { Stone cist }\end{array}$ & & $\begin{array}{l}\text { Br. ben, svin, medelstort däggdjur, } \\
\text { däggdjur } \\
\text { Burnt bone, pig, medium sized } \\
\text { mammal, mammal }\end{array}$ \\
\hline 122 & $\begin{array}{l}\text { Rund, } 6,0 \mathrm{~m} \text { diam } \\
\text { Round, diam } 6.0 \mathrm{~m}\end{array}$ & $\begin{array}{l}\text { Kantkedja, } \\
\text { skärvstenlager } \\
\text { Kerb } \\
\text { Layer of fire-cracked } \\
\text { stones }\end{array}$ & & $\begin{array}{l}\text { I keramikskärva } \\
\text { I potsherd }\end{array}$ & \\
\hline 123 & $\begin{array}{l}\text { Rund, } 4,8 \mathrm{~m} \text { diam } \\
\text { Round, diam } 4.8 \mathrm{~m}\end{array}$ & $\begin{array}{l}\text { Kantkedja } \\
\text { Kerb }\end{array}$ & $\begin{array}{l}\text { Skärvstenslager } \\
\text { Layer of fire-cracked } \\
\text { stones }\end{array}$ & $\begin{array}{l}\text { Malstenslöpare (facetterad) } \\
\text { Handstone for quern (faceted) }\end{array}$ & \\
\hline 124 & $\begin{array}{l}\text { Rund, } 4,6 \mathrm{~m} \text { diam } \\
\text { Round, diam } 4.6 \mathrm{~m}\end{array}$ & $\begin{array}{l}\text { Kantkedja } \\
\text { Kerb }\end{array}$ & & $\begin{array}{l}\text { Malstenslöpare (rundad), slagg, } \\
\text { flintsplitter (bränt) } \\
\text { Handstone for quern (rounded); } \\
\text { slag; splintered flint (burnt) }\end{array}$ & \\
\hline 125 & $\begin{array}{l}\text { Oregelbunden, } \\
4,0 \times 3,0 \mathrm{~m} \\
\text { Irregular, } \\
4.0 \times 3.0 \mathrm{~m}\end{array}$ & $\begin{array}{l}\text { Kantkedja } \\
\text { Kerb }\end{array}$ & $\begin{array}{l}\text { Skålgrop } \\
\text { Cup mark }\end{array}$ & & \\
\hline 126 & $\begin{array}{l}\text { Rund, } 7 \mathrm{~m} \text { diam } \\
\text { Round, diam } 7 \mathrm{~m}\end{array}$ & $\begin{array}{l}\text { Kantkedja } \\
\text { Kerb }\end{array}$ & & $\begin{array}{l}\text { I fullrepresenterat kärl } \\
\text { sädeskorn, skalkorn } \\
\text { I reconstructable pot; } \\
\text { Grain; hulled barley }\end{array}$ & $\begin{array}{l}\text { Br. ben, oidentifierbart } \\
\text { Burnt bone, unidentified }\end{array}$ \\
\hline 129 & $\begin{array}{l}\text { Rund, } 4,4 \mathrm{~m} \text { diam } \\
\text { Round, diam } 4.4 \mathrm{~m}\end{array}$ & $\begin{array}{l}\text { Kantkedja, } \\
\text { skärvstenlager } \\
\text { Kerb, } \\
\text { Layer of fire-cracked } \\
\text { stones }\end{array}$ & & $\begin{array}{l}\text { Keramikskärvor från 3-4 kärl } \\
\text { Potsherds of 3-4 vessels }\end{array}$ & \\
\hline 133 & $\begin{array}{l}\text { Oval, } 6,0 \times 4,3 \mathrm{~m} \\
\text { Oval, } 6.0 \times 4.3 \mathrm{~m}\end{array}$ & \begin{tabular}{|l|} 
Kantkedja \\
Kerb
\end{tabular} & \begin{tabular}{|l|} 
Kantkedja \\
Kerb
\end{tabular} & & \\
\hline 134 & $\begin{array}{l}\text { Rund, } 6,0 \mathrm{~m} \text { diam } \\
\text { Rund, diam } 6.0 \mathrm{~m}\end{array}$ & $\begin{array}{l}\text { Kantkedja, } \\
\text { skärvstenlager, } \\
\text { mittgrop } \\
\text { Kerb, } \\
\text { Layer of fire-cracked } \\
\text { stones, } \\
\text { Central pit }\end{array}$ & & & \\
\hline 135 & $\begin{array}{l}\text { Oval, } 4,3 \times 3,5 \mathrm{~m} \\
\text { Oval, } 4.3 \times 3.5 \mathrm{~m}\end{array}$ & \begin{tabular}{|l} 
Kantkedja \\
Kerb
\end{tabular} & & & \\
\hline 136 & $\begin{array}{l}\text { Rund, } 5,0 \mathrm{~m} \text { diam } \\
\text { Round, diam } 5.0 \mathrm{~m}\end{array}$ & \begin{tabular}{|l|} 
Kantkedja \\
Kerb
\end{tabular} & & & \\
\hline 137 & $\begin{array}{l}\text { Rund, } 5,0 \mathrm{~m} \text { diam } \\
\text { Round, diam } 5.0 \mathrm{~m}\end{array}$ & $\begin{array}{l}\text { Kantkedja } \\
\text { Kerb }\end{array}$ & $\begin{array}{l}\text { Skärvstenslager } \\
\text { Layer of fire-cracked } \\
\text { stones }\end{array}$ & & \\
\hline 139 & $\begin{array}{l}\text { Rund, } 5,4 \mathrm{~m} \mathrm{diam} \\
\text { Round, diam } 5.4 \mathrm{~m}\end{array}$ & $\begin{array}{l}\text { Kantkedja, } \\
\text { skärvstenlager } \\
\text { Kerb, } \\
\text { Layer of fire-cracked } \\
\text { stones }\end{array}$ & $\begin{array}{l}\text { Skärvstenslager, härd } \\
\text { Layer of fire-cracked } \\
\text { stones; } \\
\text { Hearth }\end{array}$ & & \\
\hline$|4|$ & $\begin{array}{l}\text { Oval, } 6,1 \times 5,4 \mathrm{~m} \\
\text { Oval, } 6.1 \times 5.4 \mathrm{~m}\end{array}$ & $\begin{array}{l}\text { Kantkedja } \\
\text { Kerb }\end{array}$ & $\begin{array}{l}\text { Härd } \\
\text { Hearth }\end{array}$ & $\begin{array}{l}\text { I fullrepresenterat kärl, } \\
\text { keramikskärvor från } 2 \text { kärl, } \\
\text { I knacksten } \\
\text { I reconstructable pot, } \\
\text { Potsherds from } 2 \text { vessels, } \\
\text { I hammerstone }\end{array}$ & $\begin{array}{l}\text { Br. ben, däggdjur, däggdjur (ej } \\
\text { människa) } \\
\text { Obr. ben, nöt } \\
\text { Burnt bone, mammal; mammal } \\
\text { (non-human) } \\
\text { Unburnt bone, cattle }\end{array}$ \\
\hline
\end{tabular}




\begin{tabular}{|c|c|c|c|c|c|}
\hline $\begin{array}{l}\text { Anl nr } \\
\text { ID no. }\end{array}$ & $\begin{array}{l}\text { Form, mått } \\
\text { Shape, size }\end{array}$ & $\begin{array}{l}\text { Yttre } \\
\text { formelement } \\
\text { Exterior } \\
\text { morphology }\end{array}$ & $\begin{array}{l}\text { Inre } \\
\text { Formelement } \\
\text { Interior morphology }\end{array}$ & $\begin{array}{l}\text { Fyndmaterial } \\
\text { Finds }\end{array}$ & $\begin{array}{l}\text { Osteologiskt material och } \\
\text { makrofossila cerealier } \\
\text { Osteological material and } \\
\text { macrofossil cereals }\end{array}$ \\
\hline 142 & $\begin{array}{l}\text { Oregelbunden, } 4,6 \\
\times 4 \mathrm{~m} \\
\text { Irregular, } 4.6 \times 4 \mathrm{~m}\end{array}$ & & & $\begin{array}{l}\text { Keramikskärvor från I kärl } \\
\text { Potsherds from I vessel }\end{array}$ & $\begin{array}{l}\text { Slagg, } \\
\text { Slag }\end{array}$ \\
\hline 143 & $\begin{array}{l}\text { Oval, } 6,5 \times 5,7 \mathrm{~m} \\
\text { Oval, } 6.5 \times 5.7 \mathrm{~m}\end{array}$ & $\begin{array}{l}\text { Kantkedja, } \\
\text { skärvstenlager } \\
\text { Kerb, Layer of fire- } \\
\text { cracked stones }\end{array}$ & & & \\
\hline 144 & $\begin{array}{l}\text { Kvadratisk, } 6,0 \\
\text { m sida } \\
\text { Square, sides } 6.0 \mathrm{~m}\end{array}$ & $\begin{array}{l}\text { Kantkedja, } \\
\text { skärvstenlager } \\
\text { Kerb, layer of fire- } \\
\text { cracked stones }\end{array}$ & $\begin{array}{l}\text { Inre kantkedja, } \\
\text { stenkonstruktion } \\
\text { Interior kerb; } \\
\text { Stone construction }\end{array}$ & $\begin{array}{l}\text { I fullrepresenterat kärl, } \\
\text { keramikskärvor från I kärl, } \\
\text { perforerad keramik från } 3 \text { kärl } \\
\text { (cylindrar), I glaspärla } \\
\text { I reconstructable pot, } \\
\text { potsherds from I vessel, } \\
\text { perforated pottery from } 3 \text { vessels } \\
\text { (cylinders), I glass bead }\end{array}$ & $\begin{array}{l}\text { Br. ben, nöt, större respektiva } \\
\text { medelstort däggdjur (ej människa), } \\
\text { hjortdjur (horn, rådjur?) } \\
\text { Obr. ben, nöt, får/get, däggdjur } \\
\text { Burnt bone, cattle; large and medium } \\
\text { sized mammal (non-human), deer } \\
\text { (antler roe deer?) } \\
\text { Unburnt bone, cattle, sheep/goat, } \\
\text { mammal }\end{array}$ \\
\hline 146 & $\begin{array}{l}\text { Oval, } 6,0 \times 5,6 \mathrm{~m} \\
\text { Oval, } 6.0 \times 5.6 \mathrm{~m}\end{array}$ & $\begin{array}{l}\text { Kantkedja } \\
\text { Kerb }\end{array}$ & & $\begin{array}{l}\text { I keramikskärva } \\
\text { I potsherd }\end{array}$ & \\
\hline 147 & $\begin{array}{l}\text { Rund, } 5,0 \mathrm{~m} \text { diam } \\
\text { Round, diam } 5.0 \mathrm{~m}\end{array}$ & $\begin{array}{l}\text { Kantkedja, } \\
\text { skärvstenlager } \\
\text { Kerb, } \\
\text { Layer of fire-cracked } \\
\text { stones }\end{array}$ & & & \\
\hline 148 & $\begin{array}{l}\text { Rund, } 5,0 \mathrm{~m} \text { diam } \\
\text { Round, diam } 5.0 \mathrm{~m}\end{array}$ & $\begin{array}{l}\text { Kantkedja } \\
\text { Kerb }\end{array}$ & & & \\
\hline 150 & $\begin{array}{l}\text { Rund, } 5,0 \mathrm{~m} \text { diam } \\
\text { Round, diam } 5.0 \mathrm{~m}\end{array}$ & $\begin{array}{l}\text { Kantkedja, } \\
\text { skärvstenlager } \\
\text { Kerb, layer of fire- } \\
\text { cracked stones }\end{array}$ & & $\begin{array}{l}\text { Keramikskärvor från } 3 \text { kärl, } \\
\text { malstenslöpare (facetterad), } \\
\text { järnslagg } \\
\text { Potsherds from } 3 \text { vessels } \\
\text { Handstone for quern (faceted), } \\
\text { iron slag }\end{array}$ & \\
\hline 151 & $\begin{array}{l}\text { Rund, } 4,5 \mathrm{~m} \text { diam } \\
\text { Round, diam } 4.5 \mathrm{~m}\end{array}$ & $\begin{array}{l}\text { Kantkedja, } \\
\text { skärvstenlager } \\
\text { Kerb, layer of fire- } \\
\text { cracked stones }\end{array}$ & & & \\
\hline 152 & $\begin{array}{l}\text { Rund, 5,6 m diam } \\
\text { Round, diam } 5.6 \mathrm{~m}\end{array}$ & $\begin{array}{l}\text { Kantkedja, } \\
\text { skärvstenlager, } \\
\text { brätte, } \\
\text { mittstensättning } \\
\text { Kerb, layer of fire- } \\
\text { cracked stones; } \\
\text { berm; central stone } \\
\text { setting }\end{array}$ & & & \\
\hline 154 & $\begin{array}{l}\text { Rektangulär, } \\
5,4 \times 4,3 \mathrm{~m} \\
\text { Rectangular, } \\
5.4 \times 4.3 \mathrm{~m}\end{array}$ & $\begin{array}{l}\text { Kantkedja, } \\
\text { skärvstenlager } \\
\text { Kerb, layer of fire- } \\
\text { cracked stones }\end{array}$ & & & \\
\hline 155 & $\begin{array}{l}\text { Oval, } 6,8 \times 6,2 \mathrm{~m} \\
\text { Oval, } 6.8 \times 6.2 \mathrm{~m}\end{array}$ & $\begin{array}{l}\text { Kantkedja } \\
\text { Kerb }\end{array}$ & & $\begin{array}{l}\text { Keramikskärvor från I kärl, } \\
\text { malstenslöpare (äggformad), } \\
\text { järnslagg, vridkvarn } \\
\text { Potsherds from I vessel, } \\
\text { handstone for quern (egg- } \\
\text { shaped), iron slag; rotary quern }\end{array}$ & $\begin{array}{l}\text { Br. ben, får/get, däggdjur } \\
\text { Obr. ben, nöt } \\
\text { Burnt bone, sheep/goat; mammal } \\
\text { Unburnt bone, cattle }\end{array}$ \\
\hline 156 & $\begin{array}{l}\text { Oval, 6,7 × 6,3 m } \\
\text { Oval, 6.7 x 6.3 m }\end{array}$ & $\begin{array}{l}\text { Kantkedja, } \\
\text { skärvstenlager, } \\
\text { mittgrop } \\
\text { Kerb, layer of fire- } \\
\text { cracked stones; } \\
\text { central pit }\end{array}$ & & $\begin{array}{l}\text { Keramik övrig ej i SU el FUrap/ } \\
\text { Pottery, other, not mentioned in } \\
\text { SU or FU report }\end{array}$ & \\
\hline
\end{tabular}




\begin{tabular}{|c|c|c|c|c|c|}
\hline $\begin{array}{l}\text { Anl nr } \\
\text { ID no. }\end{array}$ & $\begin{array}{l}\text { Form, mått } \\
\text { Shape, size }\end{array}$ & $\begin{array}{l}\text { Yttre } \\
\text { formelement } \\
\text { Exterior } \\
\text { morphology }\end{array}$ & $\begin{array}{l}\text { Inre } \\
\text { Formelement } \\
\text { Interior morphology }\end{array}$ & $\begin{array}{l}\text { Fyndmaterial } \\
\text { Finds }\end{array}$ & $\begin{array}{l}\text { Osteologiskt material och } \\
\text { makrofossila cerealier } \\
\text { Osteological material and } \\
\text { macrofossil cereals }\end{array}$ \\
\hline 157 & $\begin{array}{l}\text { Oval, 6,2 ×5,0 m } \\
\text { Oval, } 6.2 \times 5.0 \mathrm{~m}\end{array}$ & $\begin{array}{l}\text { Skärvstenslager } \\
\text { Layer of fire-cracked } \\
\text { stones }\end{array}$ & $\begin{array}{l}\text { Stenkonstruktion } \\
\text { Stone construction }\end{array}$ & $\begin{array}{l}\text { Keramikskärvor från I kärl } \\
\text { Potsherds from I vessel }\end{array}$ & $\begin{array}{l}\text { Br. ben, däggdjur } \\
\text { Burnt bone, mammal }\end{array}$ \\
\hline 158 & $\begin{array}{l}\text { Oval, } 5,8 \times 4,8 \mathrm{~m} \\
\text { Oval, } 5.8 \times 4.8 \mathrm{~m}\end{array}$ & & $\begin{array}{l}\text { Brandlager } \\
\text { Cremation layer }\end{array}$ & $\begin{array}{l}\text { Keramikskärvor från I kärl } \\
\text { Potsherds from I vessel }\end{array}$ & $\begin{array}{l}\text { Sädeskorn, korn, skalkorn, } \\
\text { hasselnötskal } \\
\text { Br. ben, nöt, får/get, medelstort } \\
\text { däggdjur (ej människa), fågel, } \\
\text { rovdjur (troligen mindre hund) } \\
\text { Obr. ben, nöt, får/get } \\
\text { Cerealier, skalkorn, korn (ospec), } \\
\text { obest. } \\
\text { Hasselnötskal } \\
\text { Grain, barley, hulled barley; hazelnut } \\
\text { shells. Burnt bone, cattle, sheep/goat, } \\
\text { medium sized mammal (non-human), } \\
\text { bird, carnivore (pr small dog). Unburnt } \\
\text { bone, cattle, sheep/goat. Cereals, hulled } \\
\text { barley, barley (unspec), unidentified, } \\
\text { hazelnut shells }\end{array}$ \\
\hline 159 & $\begin{array}{l}\text { Rund, } 6,0 \mathrm{~m} \text { diam } \\
\text { Round, diam } 6.0 \mathrm{~m}\end{array}$ & & & $\begin{array}{l}\text { Keramikskärvor från I kärl } \\
\text { Potsherds from I vessel }\end{array}$ & \\
\hline 162 & $\begin{array}{l}\text { Oval, } 4,7 \times 3,5 \mathrm{~m} \\
\text { Oval, } 4.7 \times 3.5 \mathrm{~m}\end{array}$ & $\begin{array}{l}\text { Kantkedja } \\
\text { Kerb }\end{array}$ & $\begin{array}{l}\text { Skärvstenlager } \\
\text { Layer of fire-cracked } \\
\text { stones }\end{array}$ & & \\
\hline $\begin{array}{l}1770 \\
\text { (FU } \\
2012)\end{array}$ & $\begin{array}{l}\text { Kvadratisk, } 4 \mathrm{~m} \\
\text { sida } \\
\text { Square, sides } 4 \mathrm{~m}\end{array}$ & $\begin{array}{l}\text { Kantkedja, } \\
\text { skärvstenlager } \\
\text { Kerb, layer of fire- } \\
\text { cracked stones }\end{array}$ & $\begin{array}{l}\text { Skärvstenslager, } \\
\text { nedgrävning, brandlager } \\
\text { Layer of fire-cracked } \\
\text { stones; pit; cremation } \\
\text { layer }\end{array}$ & $\begin{array}{l}\text { Två keramikskärvor, br. lera } \\
\text { Two potsherds; burnt clay }\end{array}$ & \\
\hline $\begin{array}{l}2049 \\
\text { (FU } \\
2012)\end{array}$ & $\begin{array}{l}\text { Rund, } 3 \mathrm{~m} \text { diam } \\
\text { Round, diam } 3 \mathrm{~m}\end{array}$ & $\begin{array}{l}\text { Skärvstenslager } \\
\text { Layer of fire-cracked } \\
\text { stones }\end{array}$ & $\begin{array}{l}\text { Skärvstenslager, } \\
\text { brandlager } \\
\text { Layer of fire-cracked } \\
\text { stones cremation layer }\end{array}$ & & $\begin{array}{l}\text { Br. ben, små fragment, kunde ej } \\
\text { tillvaratas } \\
\text { Burnt bone, fragmental, could not be } \\
\text { recovered }\end{array}$ \\
\hline $\begin{array}{l}2080 \\
\text { (FU } \\
2012)\end{array}$ & $\begin{array}{l}\text { Rund, } 6 \mathrm{~m} \text { diam } \\
\text { Round, diam } 6 \mathrm{~m}\end{array}$ & $\begin{array}{l}\text { Kantkedja, } \\
\text { skärvstenlager } \\
\text { Kerb, layer of fire- } \\
\text { cracked stones }\end{array}$ & $\begin{array}{l}\text { Brandlager } \\
\text { Cremation layer }\end{array}$ & $\begin{array}{l}\text { Keramikskärvor (2) från I kärl, } \\
\text { skålgropssten, obearbetad sten } \\
\text { av kvarts, lerklining } \\
\text { Potsherds (2) from I vessel; } \\
\text { stone with cup marks; unworked } \\
\text { quartz; clay daub }\end{array}$ & $\begin{array}{l}\text { Br. ben, nöt, ben av vuxen individ } \\
\text { samt foster/nyfödd kalv } \\
\text { Burnt bone, cattle, bone from adult } \\
\text { individual and from feutus/newborn } \\
\text { calf }\end{array}$ \\
\hline $\begin{array}{l}\text { RAÄ } \\
288 \\
(S U \\
20 I I)\end{array}$ & $\begin{array}{l}\text { Rund, } 6 \mathrm{~m} \text { diam } \\
\text { Round, diam } 6 \mathrm{~m}\end{array}$ & $\begin{array}{l}\text { Skärvstenslager } \\
\text { Layer of fire-cracked } \\
\text { stones }\end{array}$ & $\begin{array}{l}\text { Brandlager } \\
\text { Cremation layer }\end{array}$ & $\begin{array}{l}\text { Slagg } \\
\text { Slag }\end{array}$ & \\
\hline $\begin{array}{l}\text { RAÄ } \\
296 \\
(S U \\
2011)\end{array}$ & $\begin{array}{l}\text { Rund, 5,5 m diam } \\
\text { Round, diam } 5.5 \mathrm{~m}\end{array}$ & $\begin{array}{l}\text { Kantkedja, } \\
\text { skärvstenslager } \\
\text { Kerb, layer of fire- } \\
\text { cracked stones }\end{array}$ & $\begin{array}{l}\text { Brandlager } \\
\text { Cremation layer }\end{array}$ & $\begin{array}{l}42 \text { skärvor från ett kärl } \\
\text { (troligen fullrepresenterat), } \\
\text { bryne } \\
42 \text { potsherds from one vessel } \\
\text { (probably reconstructable); } \\
\text { whetstone }\end{array}$ & $\begin{array}{l}\text { Br. ben, djurben } \\
\text { Burnt bone, animal bone }\end{array}$ \\
\hline
\end{tabular}

exempel är G144, där tydliga yttre karaktärsdrag kombinerades med inre konstruktionsdetaljer och depositioner av olika typer (Fig. 4). Det fanns också exempel på mycket välbyggda anläggningar som helt saknade inre konstruktionselement och fynd (Fig. 5).

Ett tjugofemtal av de komplexa stenrösena hade färre eller mindre tydliga drag, efter en fallande skala. Dessutom fanns en grupp om ett tjugotal anläggningar, vilka endast hade ett komplext karaktärsdrag.
I det följande diskuteras mera ingående de konstruktionsdrag och fynd som förknippades med de komplexa stenrösena.

\section{Karaktärsdrag}

De komplexa stenrösenas utseende vid Farstorp kan karaktäriseras som en mindre välbyggd stensättning, eller ett mellanting mellan stensättning och röjningsröse (Fig. 6). 

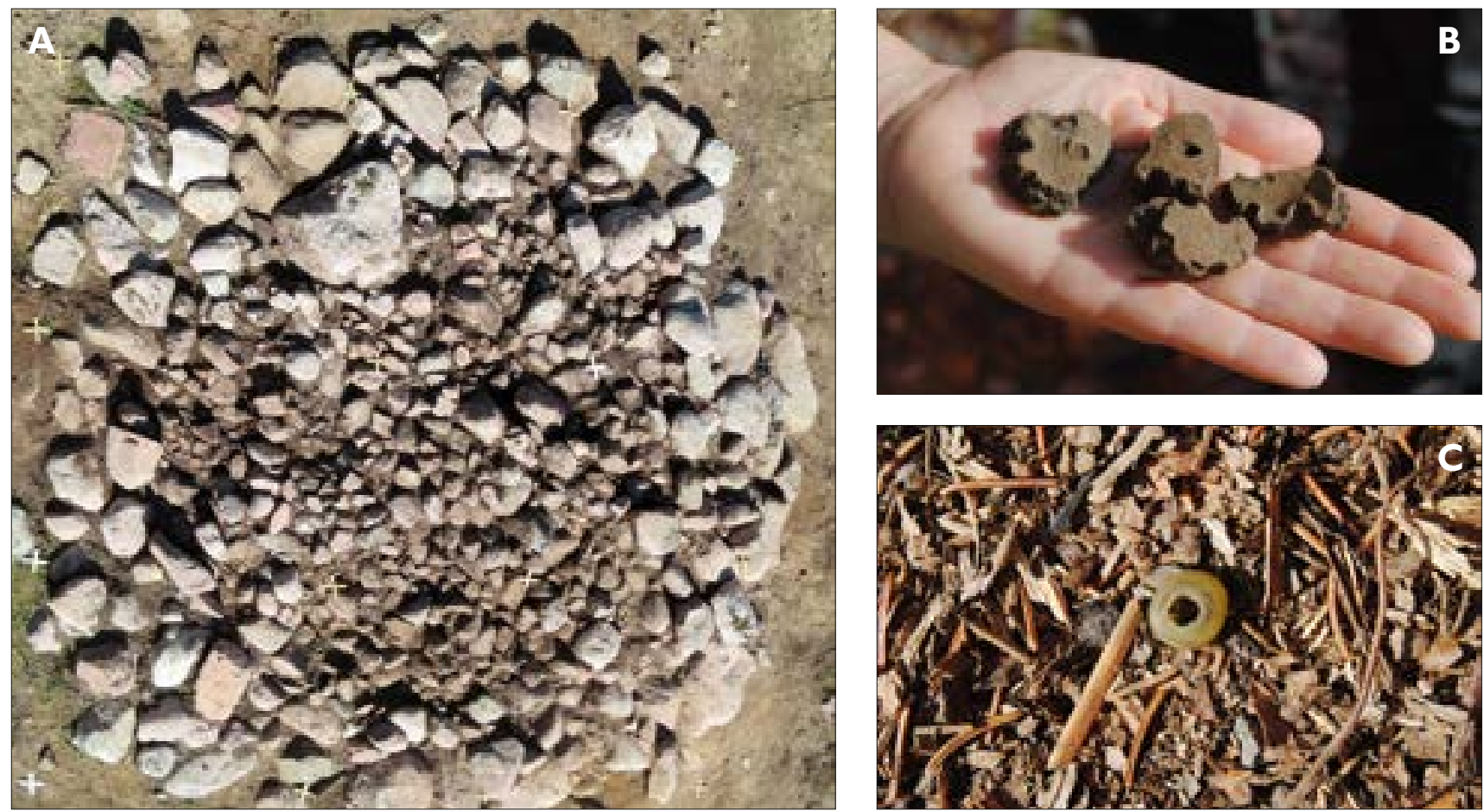

Fig 4. (kollage) GI44. 4a. Det komplexa stenröset GI44 efter framrensning. Foto: Mats Nelson, RAÄ. 4b. Perforerad keramik från GI44. Foto: Marita Sjölin, RAÄ. 4c. Gulgrön glaspärla från GI44. Foto: Marita Sjölin, RAÄ.

Fig. 4. (collage) GI44. 4a. The complex cairn GI44, after it was cleaned from soil. Photo: Mats Nelson, RAÄ. 4b. Perforated pottery from GI44. Photo: Marita Sjölin, RAÄ. 4c. Yellow-green glass bead from GI44. Photo: Marita Sjölin, RAÄ.

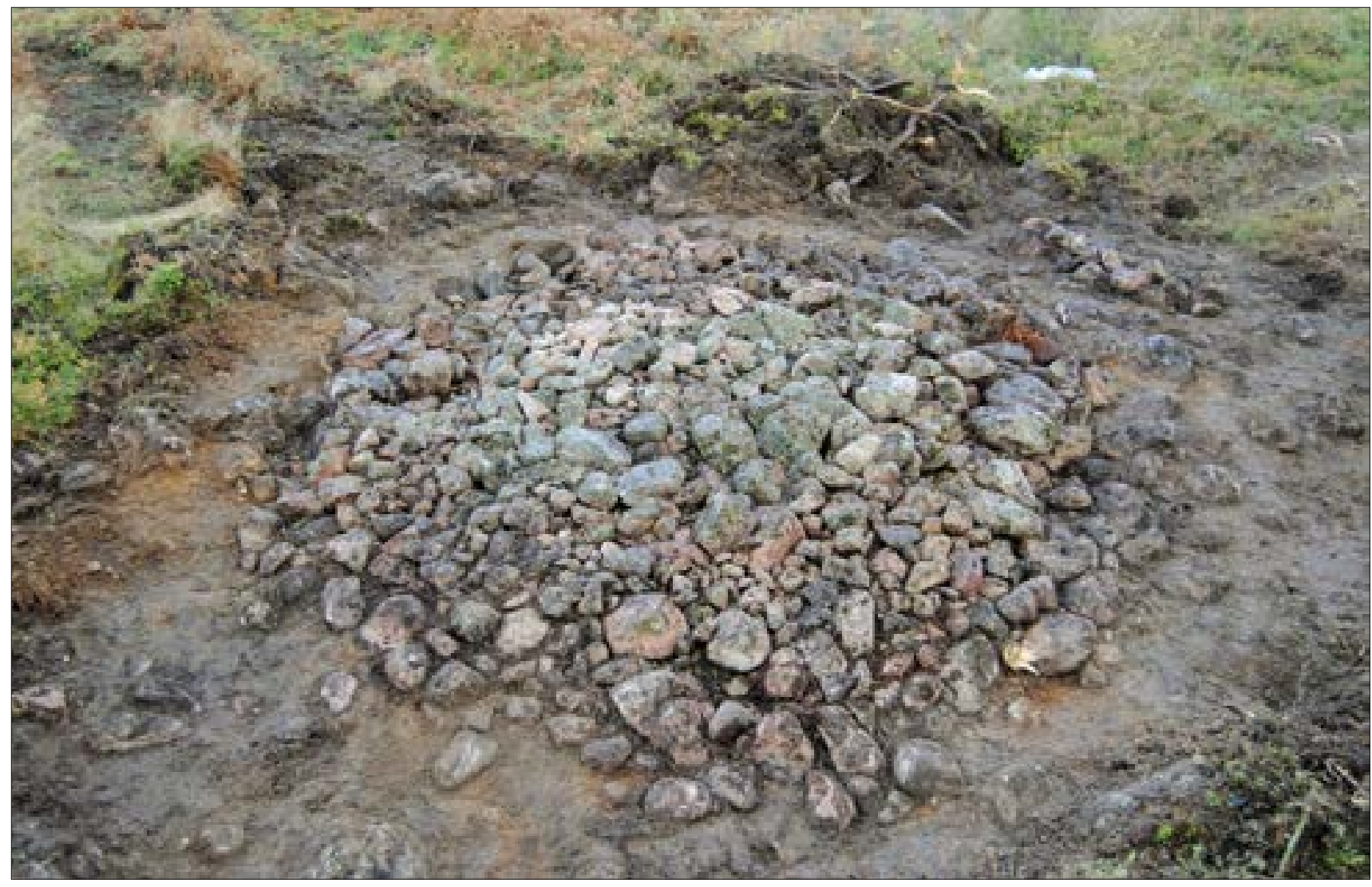

Fig 5. Det komplexa stenröset GI52 efter avbaning. Notera de större stenarna som bildar en rektangulär form. Norr är snett upP mot höger i bild. Foto: Maria Petersson, RAÄ.

Fig. 5. The complex cairn GI52, after the topsoil was removed. Note the larger stones that form a rectangular outline. North is in the direction of the top righthand side of the picture. Photo: Maria Petersson, RÄ̈. 

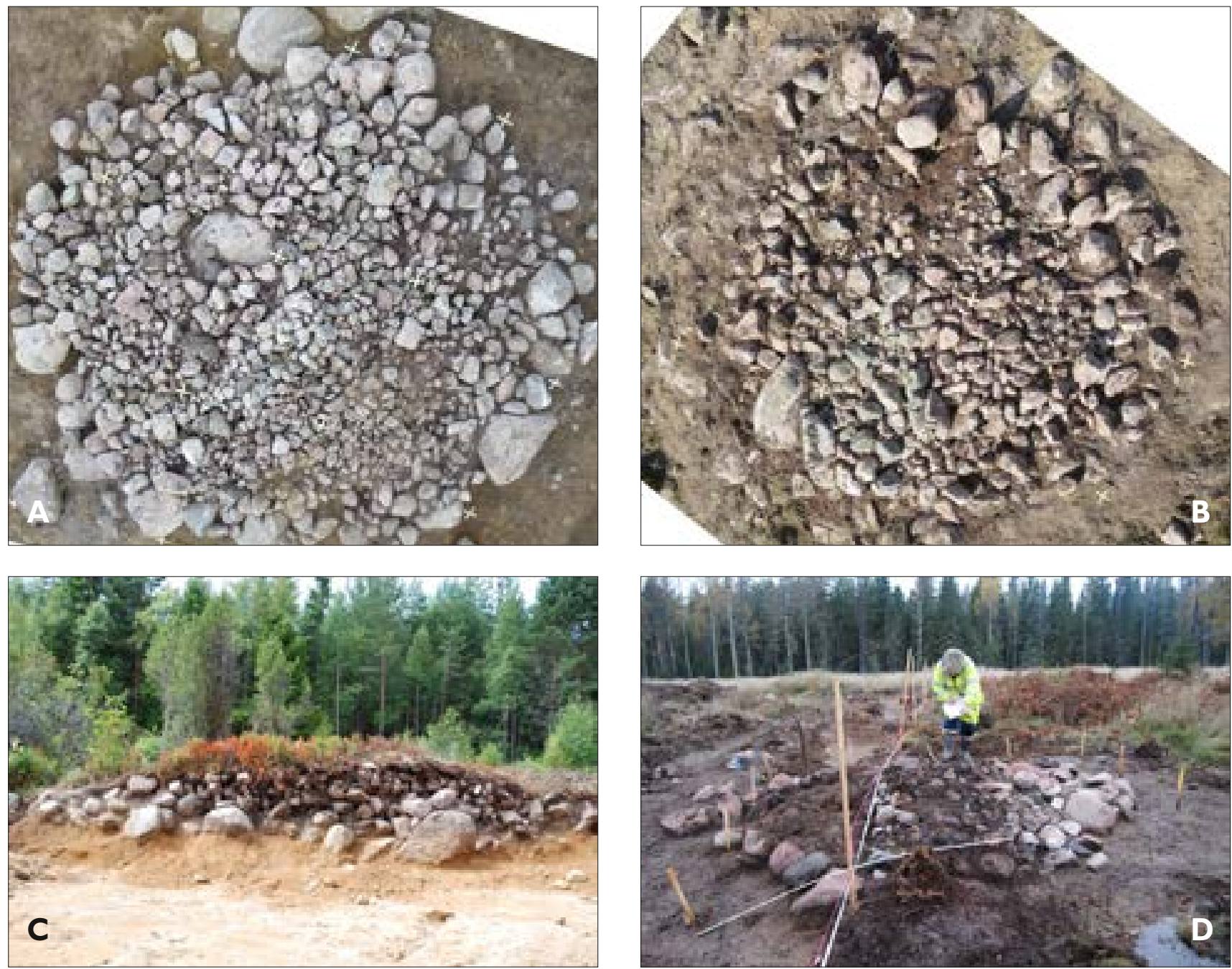

Fig 6a. GI57. Observera den jämna stenpackningen. Foto: Mats Nelsson, RÄ̈. 6b. En stenpackning med stora inslag av skärvsten täckte ytan av många komplexa stenrösen, t.ex. GI37. Foto: Mats Nelson, RAÄ. 6c. I vissa komplexa stenrösen, t ex GI05, syntes spår av flera röjningsfaser. Foto: Maria Petersson, RAÄ. 6d. Komplext stenröse med kvadratisk form. Kantkedjan var ovanligt tydlig på Al770. Foto: Marita Sjölin, RAÄ.

Fig. 6a. The complex cairn G157. Observe the even layer of packed stones. Photo: Mats Nelson, RAÄ. b. Layers of packed stones containing a multitude of fire-cracked stones covered many of the complex cairns, for example GI37. Photo: Mats Nelson, RAÄ. c. In some of the cairns, for instance G105, several clearance phases were detectable. Photo: Maria Petersson, RAÄ. d. Square complex cairns. The Kerb of AI770 was particurlarily distinct. Photo: Marita Sjölin, RAÄ.

Anläggningarna var mestadels runda eller ovala, men ett par var fyrsidiga. I regel var de 4,5-6,5 m stora och 0,5-0,6 m höga, med jämn form vad gäller såväl plan som profil. De flesta hade kantkedja av större stenar. Andra yttre konstruktionsdetaljer som förekom i enstaka fall var mittgrop och brätte.

I ytan av ungefär hälften av de komplexa stenrösena fanns en decimetertjock skärvstenspackning, där andelen skärvsten uppgick till 30-70 \%. Ibland låg skärvstenspackningen som ett utjämnande lager i mellanrummen mellan större stenar. Detta är ett drag som finns beskrivet från andra lokaler (Connelid, Mascher \& Weiler, 1993, s. 190f). Här ska noteras att Martin Rundkvist har angivit ett skärvstensinnehåll på minst 25 \% som ett kriterium för skärvstenhögar (Rundkvist,
1994, s. 83). Enbart med utgångpunkt i en ytbedömning skulle många komplexa stenrösen alltså karaktäriseras som skärvstenshögar.

Det huvudsakliga byggnadsmaterialet (fyllningen) i de komplexa stenrösena var stenar i storleksordningen $0,15-0,30 \mathrm{~m}$, vilka torde härröra från de odlingsytor som omgivit stenrösena. I några fall var det tydligt att komplexa stenrösen anlagts på tidigare odlad mark, då det fanns en åkerjordshorisont under vissa av dem. Det var också vanligt att två separata skeden av stenröjning kunde särskiljas, ibland åtskilda av en skärvstenspackning.

Det inre formspråket varierade i högre utsträckning än det yttre. Under fyllningen hade flera av de komplexa stenrösena en inre kantkedja. Tre anläggningar hade 
inre stenkistor; två var närmast kvadratiska med 0,7-1 $\mathrm{m}$ sida och en var rektangulär och $1,8 \times 0,8 \mathrm{~m}$ stor. I sju av anläggningarna fanns svarta, sotiga lager $(1,5-3,8 \mathrm{~m}$ stora) under fyllningen och nio hade skärvstenspackningar (2-3 m stora), vilket i två fall kombinerades med sotigt lager. I ett av de komplexa stenrösena fanns en drygt halvmeterstor grop med brända djurben. Inre

Tabell 3. Fynd i de komplexa stenrösena. Tabell: Maria Petersson, RAÄ.

Table 3. Finds from complex cairns. Table: Maria Petersson, RAÄ.

\begin{tabular}{|l|c|}
\hline $\begin{array}{l}\text { Fyndkategori } \\
\text { Category of finds }\end{array}$ & $\begin{array}{l}\text { Förekomst i antal } \\
\text { komplexa stenrösen } \\
\text { Occurence in numbers } \\
\text { Complex cairns }\end{array}$ \\
\hline $\begin{array}{l}\text { Brända och obrända djurben } \\
\text { Burnt and unburnt animal bone }\end{array}$ & 14 \\
\hline $\begin{array}{l}\text { Keramik (ursprungligen hela kärl) } \\
\text { (perforerad keramik)/Ceramics (originally } \\
\text { whole vessels) (perforated ceramics) }\end{array}$ & 15 (4) (I) \\
\hline $\begin{array}{l}\text { Malstenslöpare (varav 3 facetterade) } \\
\text { Handstone for quern (including 3 faceted) }\end{array}$ & $5(3)$ \\
\hline Knackstenar/Hammer stones & 5 \\
\hline $\begin{array}{l}\text { Skålgropsförekomst (varav I portabel) } \\
\text { Occurence of cup marks (including I portable) }\end{array}$ & 3 (I) \\
\hline Slagg/ Slag & 2 \\
\hline Pincett av järn/Tweezers of iron & $\mathrm{I}$ \\
\hline Pärla/Bead & $\mathrm{I}$ \\
\hline Rund sten (ekofakt)/Round stone (ecofact) & $\mathrm{I}$ \\
\hline $\begin{array}{l}\text { Borrtapp från skafthålsyxa } \\
\text { Plug from borehole of shaft-hole axe }\end{array}$ & $\mathrm{I}$ \\
\hline
\end{tabular}

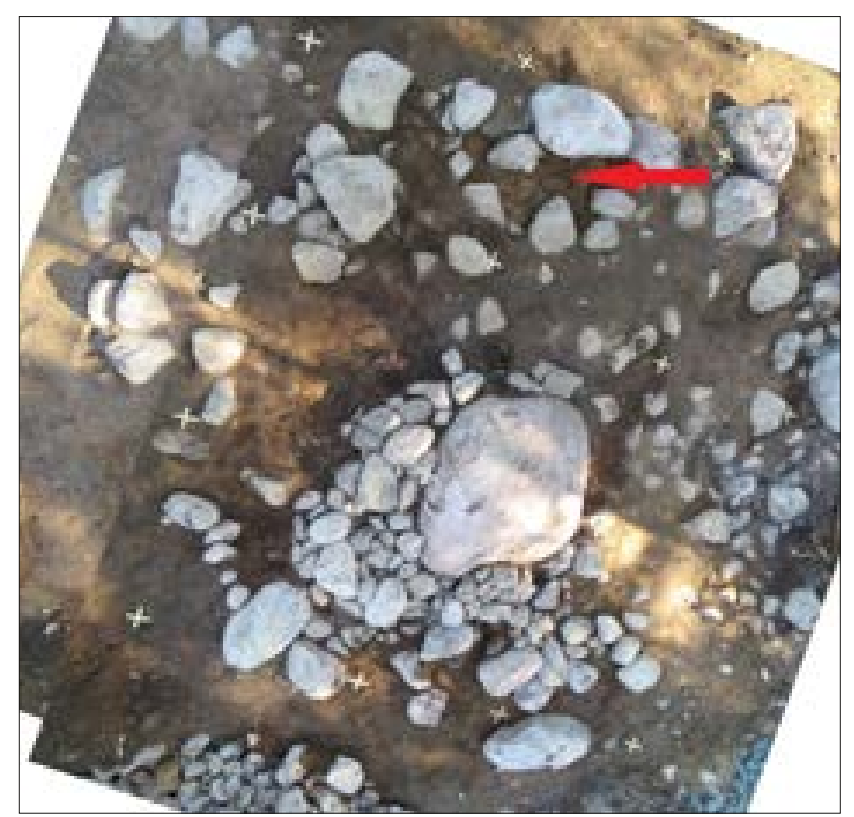

Fig 7. En inre stenkrets var byggd mot kantkedjan i GII5 (vid pilen). Inom denna fanns en koncentration av brända djurben. Foto: Mats Nelson, RAÄ.

Fig. 7. An interior ring of stones had been built just inside the kerb in the complex cairn GII5 (by the arrow), within which there was a concentration of burnt animal bones. Photo: Mats Nelson, RÄ̈. formelement som sotiga svarta lager eller gropar med brända djurben hade stora likheter med de brandgravskick som benämns brandlager och bengropar (Bennet, 1987), dock med den viktiga skillnaden att de inte innehöll några människoben (Fig. 7).

I Farstorp var de yttre formelementens formspråk gemensamt för gravar, skärvstenshögar, komplexa stenrösen och i viss mån röjningsrösen. Ungefär hälften av de komplexa stenrösena klassificerades enbart på grundval av yttre formelement och saknade såväl inre formelement som föremålsdepositioner.

\section{Fyndmaterial}

En sammanställning av fyndmaterialet från de komplexa stenrösena i Farstorp presenteras i Tabell 3. I ungefär hälften av dessa anläggningar fanns fynd av föremål eller djurben. Husdjursbenen representerar måltider och denna fyndkategori särredovisas därför nedan.

Den vanligaste fyndkategorin var keramik. I fyra fall fanns keramikkoncentrationer, vilka tolkas som rester av hela kärl som ursprungligen har ställts ner i eller intill de komplexa stenrösena (Stilborg, 2014). Kärlen har varit små till medelstora med en mynningsdiameter mellan 12 och $22 \mathrm{~cm}$. Lipidanalys visade att ett av kärlen har innehållit terrestriska animalier, dvs. landlevande djur samt växter (Isaksson, 2015). Ett annat kärl innehöll också spår av terrestriska animalier, men dessutom spår av födoämnen rika på vegetabiliska oljor som fröer och nötter. I båda fallen hade maten kommit i kontakt med rök. Keramikkärl med mat förefaller alltså ha placerats i eller intill de komplexa stenrösena. Detta verkar ha varit ett mycket vanligt förfaringssätt i rituella sammanhang under särskilt romersk järnålder och förekommer på offerplatser, i stolphål som byggnadsoffer och i gravsammanhang (Arbman, 1945; Carlie, 2004, 2009; Artelius, 2010; Petersson, 2013). Även vid kanterna av fossila åkrar från förromersk och romersk järnålder finns ibland keramikkärl (Fischer, 2007, s. 143f).

I elva av de komplexa stenrösena fanns enstaka keramikskärvor. Inget tydde på att det ursprungligen funnits hela kärl i dessa anläggningar. Skärvorna kan kanske ses som ett uttryck för pars pro toto principen, dvs en del som representerar helheten (Straume, 1984). Annet Nieuwhof har argumenterat för att delar som skärvor kan representera långväga förbindelser, minnet av döda släktingar och liknande. Kärl har då krossats vid ett särskilt, minnesvärt tillfälle, varefter skärvorna har delats ut bland deltagarna (Nieuwhof, 2015, s. 100f). Skärvorna i Farstorp kom från enkel vardagskeramik, i 
vissa fall från kokkärl. Kanske hade de kopplingar till gården och hemmet snarare än det långväga. Ett annat förslag kan vara att keramikskärvorna kom från kärl som använts som behållare för mat och dryck som konsumerats på plats. Vid sidan av kompletta kärl förekommer även en mängd enstaka keramikskärvor på de flesta av järnålderns rituella platser (Arbman, 1945; Carlie, 2009; Petersson, 2013).

I ett stenröse fanns perforerad keramik (tidigare kallat silkärl) från tre olika kärl eller cylindrar, vars storlek och utformning kunnat rekonstrueras. En del fragment kom från en mindre, trattformad cylinder, med två mynningar om 5 respektive $9 \mathrm{~cm}$ i diameter. De två andra kärlen har också varit små. Det verkar ha funnits ett samband mellan perforerad keramik och järnhantverk, men perforerad keramik verkar också ha varit associerad med offer och gravritual, kanske har de ibland fungerat som rökelsekar (Stilborg, 2008, s. 85).

I åtta av de komplexa stenrösena fanns fynd som relaterade till malning. Det rör sig om fem malstenslöpare, varav tre facetterade, samt tre knackstenar som tolkas som använda för att fräscha upp malstensunderliggare. Kasserade malstenslöpare kan ingå i det skärvstensmaterial som användes som byggnadsmaterial i olika sammanhang, t.ex. vägar och stenläggningar (Petersson, 2011; Lindeblad \& Petersson, 2012). Malstenslöpare deponerades ibland i botten av stolphål till hus och tolkas då som byggnadsoffer (Carlie, 2004). På undersökta rituella platser förekommer de regelbundet, och även i gravar, företrädesvis i fyllningen till stensättningar (Kaliff, 1992). Malstenslöpare verkar alltså under äldre järnålder ha varit förbundna med föreställningar som gör att de ibland användes i rituella sammanhang.

Knackstenar var av allt att döma vanliga under äldre järnålder, men torde vara underrepresenterade i fyndmaterialet. Randi Håland har visat att knackstenar användes för att fräscha upp malstensunderliggare, när ytan blivit alltför slät och inte längre kunnat fylla sin funktion, något som inträffade var tredje till fjärde vecka (Håland, 1987, s. 80f). Även knackstenar kan föras till den sfär som handlar om malning och säd. Liksom malstenslöpare förekommer knackstenar relativt ofta i järnålderns gravar i regionen (t.ex. Kallerskog, 2012).

I tre komplexa stenrösen fanns skålgropar. I två fall rörde det sig om enstaka skålgropar på markfasta stenblock i anläggningarnas kantkedja. I ett fall hade en drygt decimeterstor skålgropssten placerats $\mathrm{i}$ ett brandlager från yngre romersk järnålder. Sådana lösa skålgropsstenar förekommer i äldre järnålderns gravar i regionen (Häggström, 2007; Hansson, 2008). I det brandlager som innehöll en skålgropssten fanns även en obearbetad, $5 \mathrm{~cm}$ stor, rund sten av kvarts. Det är inte ovanligt att sådana ekofakter förekommer i äldre järnålderns gravar, placerade på ett sätt som inte kan vara annat än resultatet av en avsiktlig handling (Sjölin, 2015, s. 44).

I två komplexa stenrösen fanns järnslagg i kontexter daterade till folkvandringstid. I båda fallen torde det röra sig om smidesslagg, som placerats i skärvstenspackningar i anläggningarnas botten. Slagg förekommer ofta i gravsammanhang och det verkar som om magiska eller rituella föreställningar kan knytas till materialet (jfr. Burström, 1990).

En pärla av gröngult glas tillvaratogs i ett komplext stenröse, som även innehöll perforerad keramik. Pärlan hittades i fyllningen till den folkvandringstida anläggningen och låg alltså inte i någon konstruktion i dess botten. Pärlor tillhör den personliga utrustningen och förekommer allmänt i järnålderns gravar, men sällan på boplatser (jfr. Gustafsson \& Nordström, 2010). De senare årens arkeologiska undersökningar har visat att pärlor regelbundet förekommer på järnålderns rituella platser som depositioner, där Abbetorp i Östergötland och Lunda i Sörmland kan nämnas som exempel (Andersson, 2003; Lindeblad \& Petersson, 2009).

$4 \mathrm{~m}$ öster om ett komplext stenröse tillvaratogs en skänkel tillhörig en bronspincett. En skänkel tillhörig en bronspincett tillvaratogs $4 \mathrm{~m}$ öster om ett komplext gravröse. Form och material antyder att pincetten kan dateras till romersk järnålder (Rasch, 1994). Pincetter tillhör de personliga tillhörigheter som nästan uteslutande förekommer i gravar. Dock ska nämnas att det fanns en pincett, placerad i en rund byggnad, vid den rituella platsen i Abbetorp (Lindeblad \& Petersson, 2009).

Någon halvmeter från ett röjningsröse hittades en borrtapp från en skafthålsyxa. Möjligen rör det sig även här om ett deponerat föremål, som ska tolkas på samma sätt som övriga depositioner. Borrtappar förekommer ibland i gravar från järnålder, ett exempel är Vedeby i Blekinge (Åstrand, 2012).

Sammanfattningsvis kan noteras att fyndmaterialet är litet, men att sammansättningen är distinkt och uppvisare tydliga paralleller till äldre järnålderns rituella platser. Flera av de deponerade föremålen är små och av typer som brukar räknas till den personliga sfären, framför allt gäller det pärlan och pincetten. Kanske ska dessa föremål tolkas som depositioner, utförda av enskilda individer. Föremål som keramikkärlen, kan ha haft en mera generell tillhörighet till ett visst hushåll. 


\section{Djurben}

Det fanns brända och/eller obrända djurben i knappt en tredjedel av de komplexa stenrösena. Djurbenen kom från nötkreatur, får/get och tamsvin (Magnell, 2015). Fördelningen bland tamdjursarterna, baserat på antal fragment var: nöt 81 \%, får/get $15 \%$ och svin 3 $\%$. Hela djuren fanns representerade bland benen, men ben från skallar och de nedre extremiteterna var något vanligare. Tamdjursbenen tolkades i detta fall som måltidsavfall (jfr. Petersson, 2013). Som jämförelse kan nämnas att en stor andel nöt förekommer på boplatser från äldre järnålder i övergångsbygden mellan slätt och skog i Östergötland men att detta också karaktäriserar vissa rituella platser (Petersson, 2006, s. 48).

Ett mindre inslag av vilt härrör från två anläggningar (Magnell, 2015). I ett komplext stenröse fanns horn från ett större hjortdjur, sannolikt älg eller kronhjort. I en annan anläggning fanns, förutom tamdjursben, även ben från fågel samt ett mindre rovdjur eller möjligen en hund. Fågelbenet bedömdes komma från en vild fågel, mindre än tamhöns, men större än trast. Rovdjursbenet kan komma från räv eller något mårddjur, eller möjligen en hund. Ben av vilt inklusive vildfågel förekommer sällan i boplatsmaterial, men däremot i gravar, särskilt i rikare gravar från järnålder (Sigvallius, 1994). Vilt förekommer också på vissa rituella platser, ett exempel är kulthuset från vikingatid i Borg i Östergötland, där det fanns ben från bland annat kronhjort, grävling, räv och varg (Lindeblad \& Nielsen, 1997). Hund är starkt förbundet med både äldre och yngre järnålders rituella miljöer (Nielsen, 1997; Nilsson, 2009) och hundben förekommer även i samtida gravar (Gräslund, 2013).

Vid Farstorp fanns djurbenen, vanligen i de nedre delarna av de komplexa stenrösena, även om de också förekom spridda i fyllningen. Det fanns djurben i inre stenpackningar, stenkistor och i sotiga lager som liknade brandlager. Mängden djurben var liten och uppgick som mest till $100 \mathrm{~g}$ per anläggning.

Det var i några fall möjligt att fastställa djurens ålder vid slakttillfället och utifrån detta ta reda på när på året som djuren har slaktats. I en djurhållning med ett betydande inslag av utegångsdrift, kommer kornas reproduktion i hög grad att ansluta till den för vilda däggdjur, det vill säga att kalvningen sker på våren. I Farstorpsmaterialet har två får slaktats under sensommar/tidig höst och ett nötkreatur har slaktats under höst-vinter. I ett komplext stenröse i det södra området fanns brända ben från ett fullvuxet nötkretur samt en nyfödd kalv eller ett långt gånget kalvfoster. Detta indikerar händelser som inträffat under senvinter/tidig vår (Magnell, 2013). I det traditionella bondesamhället var den viktigaste årstiden för slakt senhösten, när sommarfodret började tryta och de djur som man inte hade vinterfoder till slaktades (Bringeus, 1971). Slakt under sensommar/tidig höst och senvinter/tidig vår bör därmed ha skett av andra orsaker.

\section{Komplexa stenrösen - ett handlingsperspektiv}

Med utgångspunkt i ett handlingsperspektiv har en analys av de komplexa stenrösena visat att de uppfördes på ett sätt som kan karaktäriseras som förhållandevis formaliserat; materialet tolkades som format enligt ett visst icke-slumpmässigt mönster (jfr. Berggren \& Nilsson Stutz, 2010).

I flera fall föreföll det som att komplexa stenrösen anlagts på mark som inte tidigare varit odlad. Dessa rösen representerar därmed ett första ianspråktagande av kringliggande ytor som odlingsmark. Det kunde också konstateras att flera av de komplexa stenrösena anlagts på ett odlingslager. Dessa fall tolkas som att kringliggande ytor varit odlade vid minst ett tidigare tillfälle, legat i träda under en period och därefter återupptagits som åker. Detta har inneburit förnyad stenröjning, särskilt i ett initialskede.

- I många fall var den första handling som kunde förbindas med konstruktionen, att en kantkedja av större stenar hade lagts ut.

- I ett tjugotal fall representerades en första handling på platsen av grävandet av en grop, byggandet av en packning av skärvsten eller obränd sten eller att man eldat på plats och att ett lager av kol, sot och skärvsten bildats.

- Eldandet skulle kunna ha varit förbundet med tillagning av måltider. I några andra fall har måltiderna tillagats i härdar intill stenrösena. Det var ofta svårt att avgöra om eldandet eller konstruktionen av en stenpackning, skett före utläggandet av en kantkjeda. Vid några tillfällen var det dock tydligt att så varit fallet.

- Måltider har ätits på plats. De arkeologiska spåren pekade mot att de i första hand bestått av nötkött men troligen även cerealier.

- Avfallet från måltiderna, i form av skärvsten och djurben har deponerats på platsen. Skärvsten har ibland använts för att bygga en packning av sten, på vilken djurbenen placerats. Likheterna med samtida gravar, där mänskliga kvarlevor deponerats på motsvarande vis, är påtaglig. Kanske ska depositionen 
av djurens kvarlevor här ses som en begravning, trots att det samtidigt rör sig om måltidsavfall.

- På skärvstenspackningarna, i gropar och brandlager har även keramik och enstaka andra föremål deponerats. De enstaka keramikskärvorna ska kanske också räknas till måltidsavfallet, förutsatt att skärvorna kommer från behållare som använts för att frakta t.ex. dryck till platsen.

- De djur vars kött konsumerats vid speciella tillfällen vid Farstorp kan ha slaktats på platsen, men det osteologiska materialet är alltför litet för att säkert kunna fastställa detta. Förekomst av skallar och nedre extremiteter talar för denna tolkning. Andra delar av måltiderna, särskilt dryck, bör ha förts till platsen i olika kärl.

- En möjlighet är att cerealierna ska tolkas som spår av brännoffer av säd.

- En annan typ av handling, som ibland tillhört de tidigaste på platsen, spårades i fyra av de komplexa stenrösena. Här hade en hel keramikkruka fylld med mat placerats stående på marken, i några fall verkade den ha ställts på skärvstenspackningen. I ett fall placerades en kruka strax utanför ett stenröse, något som kronologiskt frikopplar händelsen från rösebyggandet.

- Nästa moment innebar att marken i området utanför kantkedjan har bearbetats (brukats) så att sten kommit upp i ytan. Sannolikt då användes årder. Jordbearbetning torde ha skett höst och vår (jfr. Myrdal, 1985, s. 92ff).

- Härefter har sten plockats ur odlingsmarken och deponerats innanför kantkedjan. Detta moment följde tämligen omgående på de inledande måltiderna och föremålsdepositionerna. Brandlagren var nämligen intakta, inte kringdragna av betesdjur och de verkade inte heller ha hunnit bli överväxta. Depositionen av röjningssten hängde tidsmässigt samman med att kringliggande ytor tagits upp som åkermark eller att mark, som en period använts som bete efter att ha odlats, återupptagits för odling.

- En avslutande handling som kunde spåras i många av de komplexa stenrösena, var att rösets yta täckts av en stenpackning med en tjocklek av 1 till $2 \mathrm{dm}$, där en betydande del var skärvsten. Var denna skärvsten kom ifrån kunde inte fastställas. En möjlighet är att den härrörde från beredning av måltider av den typ som diskuterats ovan. Dock fanns inom området endast tolv härdar som bedömdes vara samtida med de komplexa stenrösena. Detta bedömdes som alltför få för att producera all den skärvsten som fanns i stenrösena. En annan möjlighet är att skärvstenen hade samband med den svedjning som regelbundet torde ha skett $\mathrm{i}$ området under romersk järnålder och folkvandringstid. Många markfasta stenar i området var märkbart eldpåverkade. Noterbart är att det inte hittades skärvsten i åkerjordslagren kring rösena, däremot ovanpå dem.

- I flera av de komplexa stenrösena fanns spår av upprepade röjningsskeden. Det förekom att föremål eller brända ben deponerats på den yttäckande skärvstenspackningen, varefter ett nytt lager av röjningssten deponerats på röset.

\section{Komplexa stenrösen - ett förslag till tolkning}

De komplexa stenrösena innehöll i sin uppbyggnad och utformning tydliga referenser till samtida stensättningar och gravar. Detta gäller yttre konstruktionsdetaljer som kantkedja, jämnt välvd profilform och rund planform, men också inre konstruktionsdetaljer som brandlagerlika anläggningar och inre stenpackningar. Även bruket att deponera brända ben och keramik i dessa inre konstruktioner ansluter till gravskickets utformning. Liknande idéer kan ligga bakom att brända ben från husdjur fått en behandling som liknar den av mänskliga kvarlevor. Grav eller inte blir i detta sammanhang en fråga om definitioner, där närvaron av mänskliga kvarlevor givits en avgörande betydelse i kategoriseringen.

Fyndmaterialet från de komplexa stenrösena är litet. I sin sammansättning utgör det ändå en parallell till fynd material från små rituella platser som varit viktiga i ett lokalt sammanhang (Petersson, 2013). På dessa platser hittas keramik (inklusive perforerad keramik), brända ben, skärvsten, pärlor, malstenslöpare samt ibland andra mindre föremål. Skärvsten, samt brända och obrända ben, är det mest framträdande materialet på de två typerna av lokaler och det tolkas som avfall från rituella måltider. Mary Douglas har diskuterat rent-orent i förhållande till det heliga (Douglas, 1966). Skärvsten och måltidsavfall från rituella platser kan vara så laddade att dessa kategorier måste stanna på den heliga platsen. Samma resonemang kan antagligen tillämpas på den fragmenterade keramik som är vanlig på dessa platser. Det kan röra sig om behållare som använts för att frakta dit särskilt dryck, som ofta spelat en viktig roll i rituella sammanhang (Steinsland, 2007, s. 291). Efter denna beröring med det heliga har kärlen inte längre varit användbara i andra sammanhang. Föreställningar som medfört att detta avfall fått 
en liknande hantering kan spåras från äldre järnålder fram i vikingatid (jfr. Petersson, 2013). På de rituella platserna är det också vanligt att keramikkrukor deponerats hela, vanligen med innehåll av födoämnen (Arbman, 1945; Stjernqvist, 1997; Petersson, 2013). Krukor med mat kan t.ex. ha deponerats av enskilda hushåll, de behöver inte ha utförts vid samma tillfälle som de rituella måltiderna.

Pärlor är en fyndkategori som förekommer på flera små, rituella platser, där de förefaller ha deponerats en och en. Enstaka glasskärvor från glasbägare verkar kunna ha haft samma roll som pärlor. Även andra små, personliga föremål kan förekomma som knivar, skäror och liknande. Dessa föremål skulle, på de rituella platserna, kunna vara depositioner utförda av enskilda individer, och behöver inte ha skett vid samma tillfälle som de rituella måltiderna. Det har föreslagits att ritualerna på dessa små platser med lokal betydelse har varit förknippade med fruktbarhet och årets äring (Arbman, 1945; Stjernquist, 1997; Carlie, 2009; Petersson, 2013).

Parallellerna mellan små rituella platser och de komplexa stenrösena är alltså påtagliga både vad gäller förekomsten av måltidsavfall som hanterats på ett speciellt sätt samt vad gäller fyndmaterialets sammansättning. Vi föreslår att dessa likheter även inneburit att det funnits likheter vad gäller företeelsernas idéinnehåll och att vi vid de komplexa stenrösena ser spår av ritualer. En aspekt av ritualerna kan ha varit fruktbarhet och växtkraft.

Det sparsamma fyndmaterialet i de komplexa stenrösena pekar mot att antalet deltagare vid ritualerna har varit mycket begränsat. Fynd som t.ex. pärlan har en koppling mot den personliga sfären, möjligen har vissa av föremålen deponerats av enskilda individer och med ett privat fokus, andra som keramikkrukorna med mat kan ha deponerats av några individer, t.ex. ett hushåll. Måltidsavfallet antyder att här vanligtvis funnits flera deltagare. På grund av den starka kopplingen till produktionsmarken och jordbruksarbetet är det rimligt att anta att hela eller delar av det hushåll som haft rättigheterna till marken samlats här i samband med vår- och höstbruk.

Det arkeologiska materialet pekar mot att ritualerna utfördes under våren, inför eller i samband med vårbruk och sådd, kanske också i samband med höstens jordbearbetning. En observation som pekar mot detta är tidpunkten för slakt av de djur som ingått i de rituella måltiderna. En annan observation som pekar i samma riktning är att de understa skikten av röjningssten i de komplexa stenrösena har lagts på plats i samband med eller omedelbart efter att riterna genomförts samt att detta skett i samband med jordbearbetning, troligen under höst eller vår.

Ritualerna har involverat måltider, deponeringar av hela keramikkärl, liksom av utvalda föremål som haft särskild laddning. Vidare har vissa av husdjurens kvarlevor deponerats på samma sätt som mänskliga kvarlevor (jfr. Oma, 2007). En möjlig tolkning är att riterna genomförts för att skapa goda förutsättningar för fruktbarhet och god skörd på den yta där rösena fanns. Ritualerna kan ha genomförts årligen, under de perioder när ett visst område odlats. De kan också ha genomförts i samband med inledningen av en odlingsfas i ett visst område. Cirka 50 komplexa stenrösen och en brukningstid av området som omfattar cirka 400 år, innebär att ett stenrösen tillkommit ungefär vart tionde år. Dessutom fanns enstaka depositioner som inte hade samband med tillkomsten, utan som gjorts senare, när ett område åter tagits i anspråk för odling efter ett längre uppehåll.

Från danskt område finns exempel på att keramikkärl hittats i anslutning till diken och vallar som åtskilde olika åkerytor i förromerska åkersystem (Fischer, 2007, s. 143f). Enligt Christian Fischer, kan en tolkning vara att kärlen innehållit medhavd matsäck, avsedd för de människor som arbetade på åkrarna. En annan tolkning kan vara att de innehållit matoffer «som ställts ner intill åkrarna för att säkra gudarnas välvilja och därmed god skörd» (Fischer, 2007, s. 144). Vid Store Vildmose hade ett tjugotal keramikkärl deponerats i en grop vid en åkerkant, samtidigt som åkerbruk pågick i området kring Kristi födelse (Nielsen, 1993, s. 28f). Vidare låg keramikskärvor från ett trettiotal kärl spridda kring ett block i en åkerkant. Kärlen kan ha krossats mot stenblocket, som benämns «offersten», kring 200 f.Kr.

Enstaka skålgropar framkom i flera komplexa stenrösen. Skålgropslokaler som saknar figurristningar har, enligt flera forskare, ett rumsligt samband med äldre järnålderns centrala betesmarker (Bengtsson, 2004; Innselset, 2005; Nilsson, 2017, s. 81). Detta förhållande skulle ytterligare kunna understryka de komplexa stenrösenas koppling till jordbrukets markanvändning, och i detta fall betesaspekten.

${ }^{14} \mathrm{C}$-dateringar visar att det anlagts nya komplexa stenrösen under yngre romersk järnålder och folkvandringstid, alltså under minst 350 år. I flera fall visade undersökningen att röjningsstenen hade lagts direkt på en gammal odlingshorisont. Ytan hade alltså varit odlad vid tidigare tillfälle. Möjligen ska röjningsstenen i de flesta fall sättas i samband med att ett område återupptagits som åkermark efter att det under en period använts som betesmark. Alla komplexa 
Tabell 4. Undersökta stensättningar och gravar vid Farstorp. Tabell: Maria Petersson, RAÄ.

Table 4. Excavated stone settings and burials at Farstorp. Table: Maria Petersson, RÄ̈.

\begin{tabular}{|c|c|c|c|}
\hline $\begin{array}{l}\text { Läge/objekt } \\
\text { Location/feature }\end{array}$ & $\begin{array}{l}\text { Typ, yttre formelement } \\
\text { Type, exterior morphology }\end{array}$ & $\begin{array}{l}\text { Inre konstruktioner } \\
\text { Interior constructions }\end{array}$ & $\begin{array}{l}\text { Fynd } \\
\text { Finds }\end{array}$ \\
\hline \multicolumn{4}{|c|}{ Norra gruppen/Northern group } \\
\hline $\begin{array}{l}\text { Stensättning } \\
\text { (RAÄ 289) } \\
\text { Stone setting } \\
\text { (RÄ̈ 289) }\end{array}$ & $\begin{array}{l}\text { Rund, } 5,8 \mathrm{~m} \text { i diameter, välvd profil, } \\
\text { kantkedja, jämt stenmaterial } \\
\text { Round, diameter } 5.8 \mathrm{~m} \text {, domed contour, kerb, } \\
\text { evenly sized stones }\end{array}$ & $\begin{array}{l}\text { Central } \\
\text { skärvstenspackning } \\
\text { Centrally placed layer } \\
\text { of packed fire-cracked } \\
\text { stones }\end{array}$ & $\begin{array}{l}5 \mathrm{~g} \text { brända ben, varav I människoben (klippdel } \\
\text { från tinningben pars petrosa) och I djurben, } 5 \\
\text { keramikfragment } \\
5 \mathrm{~g} \text { burnt bone, including I human bone (petrous part of the } \\
\text { temporal bone) and I anmial bone, } 5 \text { ceramic fragments }\end{array}$ \\
\hline $\begin{array}{l}\text { Omarkerad grav } \\
\text { (A5867) } \\
\text { Unmarked grave } \\
\text { (A5867) }\end{array}$ & $\begin{array}{l}\text { Grop, oval }(I, 4 \times 0,8 \mathrm{~m}, 0,25 \mathrm{~m} \text { djup}) \\
\text { Pit, oval }(I .4 \times 0.8 \mathrm{~m} \text {, depth } 0.25 \mathrm{~m})\end{array}$ & $\begin{array}{l}\text { Brandgrop } \\
\text { Cremation pit }\end{array}$ & $\begin{array}{l}4 \text { brända ben, varav I människoben (obestämt), kol } \\
4 \text { burnt bones, including I human bone (unidentified), } \\
\text { charcoal }\end{array}$ \\
\hline \multicolumn{4}{|c|}{ Mellersta gruppen/Central group } \\
\hline $\begin{array}{l}\text { Stensättning } \\
\text { (G I 45) } \\
\text { Stone setting } \\
(G \mid 45)\end{array}$ & $\begin{array}{l}\text { Rund, } 6,5 \mathrm{~m} \text { i diameter, välvd profil, } \\
\text { kantkedja, jämt stenmaterial, } 30 \% \\
\text { skärvsten i ytan, krönläge } \\
\text { Round, diameter } 6.5 \mathrm{~m} \text {; domed contour; kerb; } \\
\text { evenly sized stones, } 30 \% \text { fire-cracked stones } \\
\text { on the surface; situated on crest of hill. }\end{array}$ & $\begin{array}{l}\text { Tre gropar, flera } \\
\text { stenpackningar } \\
\text { Three pits; several layers } \\
\text { of packed stones }\end{array}$ & $\begin{array}{l}\text { Grop A: } 4 \text { fragment brända ben* } \\
\text { Grop B: I fragment brända ben* } \\
\text { Grop C: I } 8 \text { fragment brända ben* } \\
\text { Stenpackn: Keramik från 6-7 kärl, varav I perforerad } \\
\text { keramik, I järnfragment } \\
\text { I kantkedjan: I malstensunderliggare } \\
\text { I fyllningen: I obränd tand av nöt } \\
\text { *=däggdjur men ej människa } \\
\text { Pit A: } 4 \text { fragments of burnt bone* } \\
\text { Pit B: I fragment of burnt bone* } \\
\text { Pit C: I } 8 \text { fragments of burnt bone* } \\
\text { Layers of packed stones: Potsherds from 6-7 vessels, } \\
\text { including I perforated potsherd; I iron fragment. } \\
\text { Kerb: I quern stone } \\
\text { Fill: I unburnt tooth from cattle } \\
\text { *mammal non-human }\end{array}$ \\
\hline $\begin{array}{l}\text { Stensättning } \\
(\mathbf{G} \mid \mathbf{3 0}) \\
\text { Stone setting } \\
(G \mid 30)\end{array}$ & $\begin{array}{l}\text { Oval, } 4,5 \times 3,5 \mathrm{~m} \text {, kantkedja, jordblandad } \\
\text { stenfyllning med inslag av skärvsten. } \\
\text { Skärvstenspackning i ytan } \\
\text { Oval, } 4.5 \times 3.5 \mathrm{~m} \text {; kerb; fill of stones mixed } \\
\text { with soil and scattered fire-cracked stones. } \\
\text { Fire-cracked stones on surface }\end{array}$ & $\begin{array}{l}\text { I grop } \\
\text { I pit }\end{array}$ & $\begin{array}{l}\text { I grop och skärvstenslager: I I } 5 \text { g ben (varav } 57 \mathrm{~g} \\
\text { brända), } 3 \text { brända människoben (lärben samt större } \\
\text { rörben av vuxen individ), obrända ben av tamsvin och } \\
\text { nötkreatur, keramik, hartstätning, bränd lera. } \\
\text { Pit and layer of fire-cracked stones: I I } \mathrm{g} \text { bone (including } 57 \\
\mathrm{~g} \text { burnt bone); } 3 \text { burnt human bones (femur and long bone } \\
\text { from adult individual); unburnt bone from domestic pig and } \\
\text { cattle; potsherds; resin sealing; burnt clay. }\end{array}$ \\
\hline
\end{tabular}

stenrösen har i alla händelser inte tillkommit när området ursprungligen togs i anspråk som åkermark, utan de har tillkommit allt eftersom under hela perioden. Flera av de komplexa stenrösena uppvisade också tydliga spår av upprepade sten röjningsskeden.

\section{Kopplingen mellan komplexa stenrösen och gravar}

I röjningsröseområdet vid Farstorp fanns också tre stensättningar och en omarkerad grav (Tabell 4). Stensättningarna var placerade i lokala krönlägen i den norra och mellersta anläggningsgruppen. De tre stensättningarna och den omarkerade graven hade samma tidsställning som de komplexa stenrösena, de förhistoriska röjningsrösena samt den intensifierade markanvändningen, nämligen perioderna yngre romersk järnålder, folkvandringstid och tidig vendeltid.

Ett aktörsperspektiv på stensättningarna visarde att det finns förvånansvärt stor överensstämmelse med komplexa stenrösen vad gäller de handlingssekvenser som kunde utläsas ur anläggningarna. Det förekom att såväl stensättningar som komplexa stenrösen var anlagda på ett fossilt odlingslager. Handlingssekvensen har inletts med att kantkedjan lagts ut, därefter har man grävt gropar och anlagt inre stenpackningar av skärvsten, där keramik, djurben och enstaka föremål har deponerats. Skärvsten, keramik och djurben bedömdes i båda anläggningstyperna som avfall från rituella måltider. I några fall hade utvalda mänskliga kvarlevor deponerats på dessa anläggningar. Det rörde sig om benfragment av skalle och större rörben, som ursprungligen kommit från ett kremeringsbål på annan plats, men möjligen därefter förvarats för att kunna användas i tillämpliga sammanhang.

Utrymmet innanför kantkedjan har härefter fylls med röjningssten från kringliggande odlade ytor, på samma sätt som i komplexa stenrösen. I stensättningarna har stenmaterialet valts med extra omsorg för att stenarna 
Fig 8a. Stensättningen Gl45 med framrensad ytlig stenpackning av mindre stenar. Foto:

Anders Bornfalk Back, RAÄ. 8b. När den ytliga stenpackningen på stensättningen GI45 plockades bort framträdde ett lager av större stenar. Foto: Anders Bornfalk Back, RAÄ.

Fig. 8.a. The stone setting GI45, where a surface layer of packed smaller stones was uncovered. Photo: Anders Bornfalk Back, RAÄ. 8b. When this surface covering of stones was removed from the stone setting GI45, a layer of larger stones appeared. Photo: Anders Bornfalk Back, RAÄ.
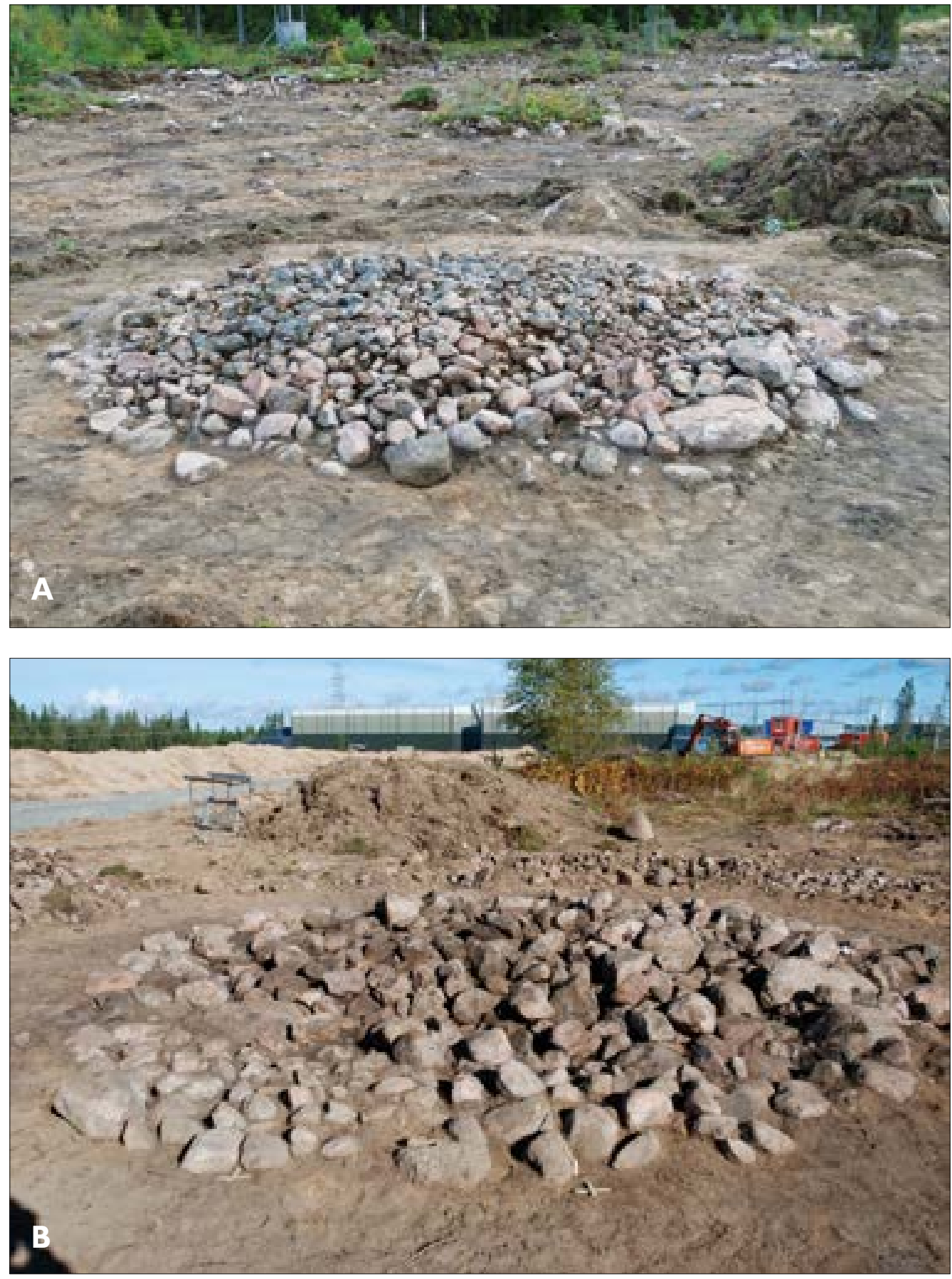

skulle vara någonlunda likstora och detta gällde även stenarna i stensättningarnas kantkedjor. En öppen fråga är om även stensättningarna byggts vid de perioder då stenar kommit upp ur åkrarna, dvs. höst och vår, eller om man då samlat ihop stenmaterialet för att använda vid senare tillfälle. Även för stensättningarna fanns en tydlig koppling till stenröjning och odling.

I likhet med de komplexa stenrösena hade skärvsten ibland deponerats på stensättningarnas yta, i avjämnande syfte (Fig. 8). I den stensättning som saknade mänskliga kvarlevor, fanns en regelrätt skärvstenspackning inom en begränsad yta ovanpå den grövre stenfyllningen och på denna fanns skärvor från sex til sju olika kärl. Skärvorna tolkades som deponerade på platsen, kanske vid olika tillfällen.

Genom att kontextuell undersökningsmetod användes har vi kunnat visa att det finns stora likheter i de handlingar och handlingssekvenser som var representerade i stensättningar respektive komplexa stenrösen. Arten av deponerat material och dateringar sammanföll i stort, medan välbyggdhet och förekomst av mänskliga kvarlevor var mera varierande. Likheterna mellan stensättningar, komplexa stenrösen och röjningsrösen får anses som påtagliga. 


\section{Avslutande kommentarer}

I den undersökta delen av röjningsröseområdet vid Farstorp fanns en rumslig uppdelning i tre grupper med röjningsrösen, komplexa stenrösen, samt i två fall stensättningar och gravar. Kronologiskt sammanföll uppförandet av de nämnda anläggningarna med en pollenanalytiskt belagd intensifiering av odling och bete i området under yngre romersk järnålder, folkvandringstid och äldsta vendeltid.

Genom sin placering är det uppenbart att järnålderns människor såg ett samband mellan dessa anläggningar och den viktigaste och mest värdefulla produktionsmarken, där markanvändningen växlat i långtidscykler mellan åker och bete. En viktig och betydelsebärande handling förefaller ha varit konstruktionen av en anläggning där element hämtade ur ett gemensamt formspråk kopplats till kult, ritual och odling.

Den handling som var tydligast företrädd i de komplexa stenrösena var konsumtion av måltider, som kan benämnas som rituella. Även stensättningar och gravar uppvisade en koppling till rituella måltider, det fanns härdar i anslutning till dessa lämningar. I en av stensättningarna fanns dessutom depositioner av brända djurben, som skulle kunna härröra från denna typ av måltider - sättet de deponerats på var helt i linje med motsvarande depositioner i de komplexa stenrösena. Har även betydelsen av måltiderna haft liknande karaktär? Hade även måltiderna som tillagats vid stensättningarna en koppling till produktionsmarken och jordbruksåret?

Det har också varit viktigt att deponera föremål med speciell laddning i de komplexa stenrösena. En stor grupp föremål kopplas till säd och malning - något som kanske antyder det förhärskande temat i riterna. Det förekom också keramikkärl fyllda med mat. Riterna kopplade till de komplexa stenrösena kan sannolikt hänföras till specifika moment i jordbruksåret - höstens jordbearbetning och vårbruk med sådd.

Föremålsbeståndet och lämningarnas karaktär skulle kunna tolkas som att riterna på plats omfattat förhållandevis få personer, ett förslag är att det rörde sig om medlemmar ur det hushåll, som hade förfoganderätt över marken. De små föremålen skulle kunna tolkas som depositioner av enskilda individer, men kanske har dessa personer agerat som delar av ett kollektiv, nämligen hushållet.

För den stensättning vid Farstorp som saknade mänskliga kvarlevor skulle samma resonemang och tolkning som för de komplexa stenrösena kunna vara relevant. Det är då inte avsaknaden av människoben som definierar vad den symboliserat i ett förhistoriskt samhälle. Brända djurben tolkas som deponerat avfall från rituella måltider. Den malstensunderliggare som fanns i kantkedjan tolkas som en allusion på sädesodling och önskan om fruktbarhet, i enlighet med tolkningen av de komplexa stenrösena.

När mänskliga kvarlevor fanns i anläggningarna, rörde det sig om enstaka utvalda ben. Sättet de deponerats på har paralleller i depositionerna i de komplexa stenrösena. En aspekt av dessa depositioner skulle, i likhet med de komplexa stenrösena, kunna vara kopplingen till produktionsmarken och ett sätt att försöka försäkra sig om fruktbarhet och växtkraft. En hypotes kan vara att benen kom från döda medlemmar av det hushåll, som innehaft dispositionsrätten till marken i området. Förfäderna har haft en särskild koppling till området och familjen - de kan ha förväntats agera till förmån för sina levande släktingar även efter sin död (jfr. Nieuwhof, 2015). I så fall är det också möjligt att placeringen av döda förfäders ben inom produktionsmarken varit ett sätt att demonstrera och förstärka markrättigheter. Att se stensättningar i röjningsröseområden enbart som den slutliga viloplatsen för döda är i alla händelser en grov förenkling.

I flera fall är det tydligt att de brända djurbenen deponerats på samma sätt som människoben, både i de komplexa stensättningarna och i den stensättning där människoben saknades. Detta antyder möjligheten av att det funnits paralleller mellan de döda husdjurens roll och den roll döda familjemedlemmar spelat i detta rituella sammanhang.

På ett överordnat plan finns strukturella likheter mellan olika kategorier av lämningar; gravar, röjningsrösen, komplexa stenrösen och skärvstenshögar såväl vad gäller yttre formspråk och material som inre konstruktioner och depositioner av olika typ och sammansättning. Gemensamma bakomliggande föreställningar verkar var orsaken till detta och gränserna mellan kategorierna har därmed begränsad relevans i förhållande till förhistoriska förhållanden.

De resultat som presenterats i artikeln visar med all önskvärd tydlighet att frågan «Grav eller röjningsröse», som ofta ställs i samband med undersökningar av röjningsröseområden, inte är relevant i förhållande till en förhistorisk verklighet. Vid Farstorp fick vi istället möjlighet att arbeta med lämningarna med utgångspunkt från ett handlingsperspektiv. Vi har försökt att se vad förhistoriens människor gjort, istället för att kategorisera utifrån bevarade lämningar. Vi har sett att förhistoriska aktiviteter i förhållande till röjningsröseområden har varit komplexa och mångfacetterade. Vi har också sett att landskapet och platsen, 
jordbruksarbetet, föreställningar om magi och ritual kopplade till fruktbarhet och växtkraft, dispositionsrätter för mark och förfädernas vakande hand över sina efterkommande varit sammanvävda. Detta har kommit till uttryck i landskapet där komplexa handlingskedjor har fokuserats på enskilda anläggningar av många olika typer. Frågeställningen grav eller röjningsröse är alltför förenklad och tar inte hänsyn till detta.

\section{Summary}

At Farstorp near Nässjö, a tenth part of a clearance cairn site, 45 hectares in size, was excavated. A central theme of the excavation concerned differences between graves and clearance cairns. The excavation comprised fossil fields, clearance cairns, graves and so called complex cairns. The latter were mainly constructed of clearance stones. Construction and design, such as the evenly arched cross-section and rounded plan, kerbs and even interior details such as packed stones and layers similar to cremation layers were distinct references to contemporaneous stone settings and burials. Further, deposited burnt bones and pottery in these interior constructions relate to burial customs, although human remains are entirely lacking.

The assemblage of finds from these complex cairns is sparse. However, their composition constitutes a parallel to assemblages from small ritual sites, central in local contexts (Petersson, 2013). Fire-cracked stones along with burnt and unburnt bones are the most common finds, interpreted as waste from ritual meals. Runners for querns, querns and hammerstones used to peck quern stones into shape, are artefacts associated with grain and grinding of grain - perhaps indications of a significant ritual theme. Ceramic vessels filled with food had been placed in several of the constructions. Single potsherds are more difficult to interpret. Rituals on the site appear to have been performed in conjunction with agricultural activities in spring and/or autumn.

Chronologically, construction of clearance cairns, complex cairns and burials coincides with a period, confirmed through pollen analysis, of intensified agriculture and grazing during late Roman Iron Age, Migration Period and early Vendel Period.

The placing of the features suggests that the Iron Age people saw a connection between these constructions and the invaluable farmland, used in long-term cycles alternating between grazing and cultivation. Constructing monuments appears to have been a significantly meaningful act; aspects of a common idiom were associated with cult, rituals and farming.

The assemblage of finds and the character of the constructions indicate that rituals performed on the site involved only few people, possibly members of a household with the right to farm the land. Small artefacts such as a bead and a pair of tweezers imply depositions made by individuals, who may have acted as part of a collective; a household.

It is evident from the results presented in the article that the question of 'grave or clearance cairn', which is often discussed during excavations of clearance cairn sites, is not a relevant question in relation to prehistoric conditions. At Farstorp we had the opportunity of working with remains from the perspective of activities that were performed. Instead of categorizing remains, we have tried to find out what prehistoric people did. We have found that prehistoric activities associated with clearance cairn sites were complex and multifaceted. We have also seen that the landscape and the site, along with farm work, ideas about magic and rituals associated with fertility and growth, as well as land use rights and ancestors who are keeping an eye on their descendants, were all interlaced. This has been expressed in the landscape where individual features of a variety of types were the focus of complex chains of activities. The question of grave or clearance cairn is too simplified and does not take this into account.

\section{Referenser}

RA ̈̈= Riksantikvarieämbetet

Ajneborn, B. (2013). Sydvästlänken. Delsträckan BarkerydVärnamo. Arkeologiska föundersökningar genom södra och norra delarna av Jönköpings län. Småland, Nässjö och Värnamo kommuner, Barkeryd, Nässjö och Tännö socknar. RAÄ dnr 422-00696-2012. Rapport 2013:37. Stockholm: RAÄ.

Alering, Å. (2010). Fossilt landskap i modern tid. Fornlämningsmiljöer $i$ småländsk skogsmark. Steg 2. Studier av arkeologiska undersökningar i Kronobergs län. Rapport 2010:15. Växjö: Smålands museum.

Andersson, G. (2003). Lunda gård - delområde E «Lunden» - en plats för aktiviteter under förhistorisk och historisk tid. E20 Södermanland, Strängnäs socken, Strängnäs 2:23, RAÄ 266. RAÄ UV Mitt. Rapport 2003:6. Stockholm: RAÄ.

Andersson, H. \& Widgren, M. (Red.). (2016). Kan man leva på en ödegård? Huvudgårdar, landbotorp och odlingssystem under medeltid i Lägerbobygden, Östergötland. KVAHH handlingar. Antikvariska serien 53. Stockholm: Kungl. Vitterhets Historie och antikvitets Akademien.

Arbman, H. (1945). Käringsjön. Studier i halländsk järnålder. KVHAA:s handlingar del 59:1. Stockholm: Wahlström \& Widstrand.

Artelius, T. (2010). Den gamla döden och den nya. Om vikingatidens förkristna begravningar, religiösa riter och religionsskiftet. Jönköping: Jönköpings läns museum.

Ashmore, W. \& Knapp, B. (Red.).(1999). Archaeologies of landscape. Contemporary perspectives. Oxford: Blackwell Publishers.

Bell, C. (1992). Ritual theory, ritual practice. New York: Oxford University Press.

Bellander, E. (1938). Bålrösen - offerrösen. Kulturhistoriska studier tillägnade Nils Åberg. Stockholm: Generalstabens litografiska anstalts förlag, 91-100.

Bengtsson, L. (2004). Bilder vid vatten. Kring hällristningarna i Askums sn, Bohuslän. Gotarc Series C. Arkeologiska Skrifter No. 51. Göteborg: Göteborgs Universitet.

Bennett, A. (1987). Graven - religiös och social symbol: strukturer i folkvandringstidens gravskick i Mälarområdet. (Doktorsavhandling.) Stockholms universitet, Stockholm.

Berg, J. (2003). Gods och landskap. Jordägande, bebyggelse och samhälle i Östergötland 1000-1562. (Doktorsavhandling.) Stockholms universitet, Stockholm.

Berggren, Å. \& Nilsson Stutz, L. (2010). Ett utmanande koncept. I A. -C. Hornborg (Red.), Den rituella människan 
- flervetenskapliga perspektiv. Linköping: Linköping University Electronic Press. Hämtat från http://urn.kb.se/ resolve?urbn=urn:nbn:se:liu:diva-58921

Berglund, B. \& Börjesson, K. (Red.).(2002). Markens minnen. Landskap och odlingshistoria på småländska höglandet under 6000 år. Stockholm: RAÄ.

Björkhager, V. (1992). Kenotafer - finns de? En undersökning av gravmaterial från Uppland och Södermanland. (CDuppsats i arkeologi.) Uppsala universitet, Uppsala.

Björkman, L. (2014). Pollenanalytisk undersökning av en lagerföljd från Staplakärret och jordprover från fornlämningen RÄ̈ 295 (Barkeryds socken) vid Farstorp i Nässjö kommun. Nässjö: Viscum pollenanalys \& miljöhistoria. (Bilaga 9 i Petersson, 2016,)

Botwid, K. (2016). The artisanal perspective in action: An archaeology in practice. (Doktorsavhandling.) Lunds universitet, Lund.

Bringeus, N. -A. (1971). Arbete och redskap. Materiell folkkultur på svensk landsbygd före industrialismen. Lund: Gleerup.

Burström, M. (1990). Järnframställning och gravritual: en strukturalistisk tolkning av järnslagg i vikingatida gravar. Fornvännen 1990 (85), 261-271.

Carelli, P. (2001). En kapitalistisk anda. Kulturella förändringar i 1100-talets Danmark. (Doktorsavhandling.) Lunds universitet, Lund.

Carlie, A. (2004). Forntida byggnadskult. Tradition och regionalitet i södra Skandinavien. RA ̈̈, Arkeologiska skrifter No 57. Stockholm: RAÄ.

Carlie, A. (2009). Käringsjön - en gammal fyndplats i ny belysning. I A. Carlie (Red.), Järnålderns rituella platser. Femton artiklar om kultutövning och religion från en konferens $i$ Nissaström den 4.-5. oktober 2007 (s. 225-264). Halmstad: Kulturmiljö Halland.

Connelid, P., Mascher, C. \& Weiler, E. (1993). Röstorp - ett västsvenskt röjningsröseområde i skogsmark. Arkeologi $i$ Sverige. Ny följd 2. Stockholm: RA Ä, 15-38.

Douglas, M. (1966). Purity and danger. An analysis of concepts of pollution and taboo. London: Routledge \& K Paul.

Engman, F., Lorenzon, M. \& Vestbö-Franzén, A. (2015). Odling och markutnyttjande. Ett syntesarbete utfrån undersökningar av fossil åkermark $i$ Jönköpings län. Jönköping: Jönköpings läns museum.

Fischer, C. (2007). Tollundmanden: gaven til guderne: mosefund fra Danmarks forhistorie. Højbjerg: Hovedland.

Gren, L. (1989). Det småländska höglandets röjningsrösen. Arkeologi i Sverige 1986. Stockholm: RAÄ, 73-96.

Gren, L. (1991). Fossil åkermark. Fornlämningar $i$ Sverige 1. Stockholm: RAÄ.

Gräslund, A. -S. (2013). Kristna inslag i Gamla Uppsala och dess närområde. Gamla Uppsala i ny belysning. I O. Sundqvist \& P. Vikstrand (Red.), Gamla Uppsala $i$ ny belysning (s. 113-134). Uppsala: Swedish Science Press.

Gustafsson, J. \& Nordström, M. (2010). Döden i Torsvik. Tre järnåldersgravfält $i$ södra Vätterbygden berättar om gravritualer, sydportar och brännportar. Jönköping: Jönköpings läns museum.

Gustawsson, K. A. (1949). Kokstenshögar. Fornvännen, 133-165.

Hansson, M. (2008). En gammal grävning, ett kulthus och ett antikvariskt problem. I J. Goldhahn (Red.), Gropar E monument. En vänbok till Dag Widholm (s. 147-169).
Kalmar: Humanvetenskapliga institutionen, Högskolan i Kalmar.

Harris, E. C. (1979). Principles of archaeological stratigraphy. London: Acad. P.

Holm, I. (2004). Forvaltning av argrare kulturminner i utmark. Upublisert doktorgradsavhandling i arkeologi. Arkeologisk institutt, Universitetet i Bergen, Bergen.

Hyenstrand, Å. (1968). Skärvstenshögar och bronsåldersmiljöer. TOR XII, 61-79.

Hyenstrand, Å. (1984). Fasta fornlämningar och arkeologiska regionindelningar. Rapport 1984:7. Stockholm. Riksantikvarieämbetet och Statens historiska museer.

Håland, R. (1987). Socio-economic differentiation in Neolithic Sudan. Cambridge Monographa in African Archaeology 20. BAR International Series 350. Cambridge: BAR.

Häggström, L. (2005). Landskapsutnyttjande, bete och odling på sydsvenska höglandet under äldre järnålder. Exemplet Öggestorp. (Doktorsavhandling.) Göteborgs universitet, Göteborg.

Häggström, L. (2007). Monument eller liklös grav? Om tolkningar av gravar och monument utan tydlig gravläggning. I L. Häggström (Red.), Öggestorp $\mathcal{E}$ Rogberga. Vägar till småländsk förhistoria (s. 55-78). Jönköping: Jönköpings läns museum.

Innselset, S. 2005. Skålgropene i Valdres og indre Sogn - ikkje berre 'stølsristningar'? I K. A. Bergsvik \& A. Engevik jr. (Red.), Fra funn til samfunn. Jernalderstudier tilegnet Bergljot Solberg på 70-årsdagen (s. 69-90). UBAS. Bergen: Universitetet i Bergen.

Isaksson, S. (2015). Analys av organiska lämningar $i$ keramik från Farstorp. Stockholms universitet. Institutionen för arkeologi och antikens kultur. Arkeologiska forskningslaboratoriet. Auxilia. Uppdragsrapport nr 253. Stockholm. (Bilaga 12 i Petersson, 2015.)

Janson, G. (1999). Stensättningar och rösen vid sidan om. En studie av kvadratiska stensättningar och rösen i Kronobergs län. (C-uppsats i arkeologi.) Kalmar högskola, Kalmar.

Kaliff, A. (1992). Brandgravskick och föreställningsvärld. En religionsarkeologisk diskussion. (Licenciatavhandling.) Uppsala universitet, Uppsala.

Kaliff, A. (1994). Skärvstenshögar och kremeringsplatser. Exempel och experiment med utgångspunkt från en utgrävning i Ringeby, Kvillinge sn, Östergötland. TOR 26, $35-56$.

Kaliff, A. (1997). Grav och kultplats. Eskatologiska föreställningar under yngre bronsålder och äldre järnålder $i$ Östergötland. (Doktorsavhandling.) Uppsala universitet, Uppsala.

Kaliff, A. (1999). Objekt och tanke. Speglingar av bronsålderns föreställningsvärld. I M. Olausson (Red.), Spiralens öga. Tjugo artiklar kring aktuell bronsåldersforskning (s. 91-114). RAÄ, Arkeologiska undersökningar. Skrifter nr. 25. Stockholm: RAÄ.

Kallerskog, L. (2012). Domarring i Porteshult. Arkeologisk undersökning av domarring RÄ̈ Månsarp 41:2 med anledning av skadegörelse $i$ samband med kraftledningsarbeten, Månsarps socken i Jönköpings kommun, Jönköpings län. Jönköpings läns museum: Jönköping.

Kraft, A. (2005). Röjningsrösen som transitionsmonument: en diskussion kring gravar i röjningsröseområden. I P. Lekberg (Red.), Texter kring ting och tid: arkeologiska 
fenomen i Kronobergs län (s. 95-114). Växjö: Kulturspridaren.

Lagerås, P. (2000). Järnålderns odlingssystem och landskapets långsiktiga förändring. Hamnedas röjningröseområden i ett paleoekologiskt system. I P. Lagerås (Red.), Arkeologi och paleoekologi i sydvästra Småland. Tio artiklar från Hamnedaprojektet (s. 167-229). Stockholm: RAÄ.

Lagerås, P. (2013). Agrara fluktuationer och befolkningsutveckling på sydsvenska höglandet tolkade utifrån röjningsrösen. Fornvännen 108 (2013), 263-276.

Lindeblad, K. \& Nielsen, A. -L. (1997). Kungens gods $i$ Borg. Om utgrävningarna vid Borgs säteri. Arkeologisk slutundersökning, Borgs säteri 6702, RÄ̈ 276, Borgs socken, Norrköpings kommun, Östergötland. Linköping: RAÄ.

Lindeblad, K. \& Petersson, M. (2009). Riter kring berg, block och vatten - om utgrävningarna vid Abbetorp i västra Östergötland. I A. Carlie (Red.), Järnålderns rituella platser. Femton artiklar om kultutövning och religion från en konferens i Nissaström den 4.-5. oktober 2007 (s. 101-138). Halmstad: Kulturmiljö Halland.

Lindeblad, K. \& Petersson, M. (2012). Mörtlösa bytomt gårdar från järnålder och historisk tid. Östergötland, Linköpings kommun, S:t Lars socken, RA ̈̈ 323 m.fl. Dnr 423-00337-2007. RAÄ, UV rapport 2012:50. Stockholm: RAÄ.

Lundqvist, L. (1991). Undersökta skärvstenshögar i Västsverige. Arkeologi i Sverige. Ny följd 1. Stockholm: RAÄ, 43-60.

Magnell, O. (2013). Djurben från FU Farstorp (RAÄ 295), Barkeryds socken, Jönköpings län. Lund: RAÄ. (Bilaga 7 i Sjölin, 2013a).

Magnell, O. (2015). Analys av osteologiskt material från Farstorp, Barkeryd RAÄ 295, Kramsäng 1:2, 1:11 och Ryssby 2:11, Jönköpings län. Mars 2015. Lund: SHMM, Arkeologiska uppdragsverksamheten. (Bilaga 5 i Petersson 2015).

Mascher, C. (Red.).(2002). Agrarhistorisk landskapsöversikt: Västergötland och Dalsland. Göteborg: Länsstyrelsen Västra Götaland.

Mjærum, A. (2012) Åkre og beitemark i Fevanggrenda. Nytt om jernalderlandbruket i Vestfold. Viking LXXV, s. $109-130$.

Molander, B. (1996). Kunskap i handling. Göteborg: Daidalos.

Myrdal, J. (1985). Medeltida åkerbruk. Agrarteknik i Sverige ca. 1000 till 1520. Stockholm: Nordiska museet.

Nielsen, A. -L. (1997). Pagan cultic and votive acts at Borg. I H. Andersson, P. Carelli \& L.Ersgård (Red.), Visions of the past. Trends and traditions. Studies in Swedish medieval archaeology (s. 373-392). Stockholm: RAÄ.

Nielsen, V. (1993). Jernalderens pløjning. Store Vildmose. Vendsyssel: Vendsyssel historiske museum.

Nieuwhof, A. (2015). Eight human skulls in a dung heap and more. Ritual practice in the terp region of the northern Netherlands $600 B C-A D$ 300. Groningen: Barkhuis publishers and University of Groningen Library.

Nilsson, C. (1987). Gravundersökningar i Östergötland åren 1967-84. I T. Andrae, M. Hasselmo \& K. Lamm (Red.), 7000 år på 20 år. Arkeologiska undersökningar $i$ Mellansverige (s. 79-108). Stockholm: RAÄ.

Nilsson, L. (2009). Häst och hund i fruktbarhetskult och blot. I A. Carlie (Red.), Järnålderns rituella platser. Femton artiklar om kultutövning och religion från en konferens $i$
Nissaström den 4.-5. oktober 2007 (s. 81-100). Halmstad: Kulturmiljö Halland.

Nilsson, P. (2017) Brukade bilder. Södra Skandinaviens hällristningar ur ett historiebruksperspektiv.

(Doktorsavhandling.) Stockholms universitet, Stockholm.

Norman, P. (1989). Röjningsrösen och förhistoriska gravar. Arkeologi i Sverige 1986. RA ̈̈ Rapport 1988:2, Stockholm: RAÄ, 97-109.

Nylén, E. (1958). Pryda, skydda, binda? Om gravskickets mening och skärvstensrösenas problem med anledning av ett aktuellt bronsåldersfynd. Gotländskt arkiv 1958, 23-38.

Oma, K. A. (2007). Human - animal relationships. Mutual becomings in Scandinavia and Sicilian households 900-500 BC. Oslo Arkeologiske Serie Nr. 9. Oslo: Unipub.

Pedersen, E. A. \& Widgren, M. (1998). Järnålder, 500 f.Kr.1000 e.Kr. I S. Welinder, E. A. Pedersen \& M. Widgren. Det svenska jordbrukets historia. Jordbrukets första femtusen år. 4000 f.Kr.-1000 e.Kr. (s. 239-459). Stockholm: Natur och Kultur.

Petersson, M. (1999). Arkeologiska utgrävningar av fossil åkermark - en metodstudie. I A. Ericsson (Red.), Odlingslandskap och uppdragsarkeologi. Artiklar från Nätverket för arkeologisk agrarhistoria (s. 61-73). RAÄ. Skrifter nr 29; Stockholm: RAÄ.

Petersson, M. (2006). Djurhållning och betesdrift. Djur, människor och landskap $i$ västra Östergötland under yngre bronsålder och äldre järnålder. (Doktorsavhandling.) Uppsala universitet, Uppsala.

Petersson, M. (2011). Ett nät av vägar. Arkeologi i Östergötland, 11-12.

Petersson, M. (2013). Hulje - Calendrical rites along a small stream. Electronic Journal of Folklore 55. (http://www. folklore.ee/folklore/vol55/petersson.pdf)

Petersson, M. (Red.). (2015). Farstorp - ett röjningsröseområde i långtidsperspektiv. Småland, Nässjö kommun, Barkeryds socken, Kramsäng 1:2 och 1:11 samt Ryssby 2:11, RA ̈̈ 287, 295, 358, 362, 363, 364, 371. SHMM dnr 5.1.1-00369-2015. Rapport 2015:116. Stockholm: Statens historiska museer, Arkeologiska uppdragsverksamheten.

Rasch, M. (1994). The appearance of weapon graves in Scandinavia around the Birth of Christ: some interpretations in the light of weapon graves from Öland. I C. von Carnap-Bornheim (Red.), Beiträge zu römischer und barbarischer Bewaffnung in den ersten vier nahchristlichen Jahrhunderten. Akten des 2. Internationalen Kolloquiums in Marburg a.d. Lahn, 20. bis 24. Februar 1994 (s. 223-231). S. Marburg: Vorgeschichtliches Seminar der Phillips-Univ.

Rentzhog, S. (1967). Om skärvsten och skärvstensrösen. TOR $X I, 61-82$.

Rundkvist, M. (1994). Skärvstenshögar med gravgömmor i östligaste Mälarområdet. Fornvännen 89, 83-89.

Röst, A. 2016. Fragmenterade platser, ting och människor. Stenkonstruktioner och depositioner på två gravfältslokaler i Södermanland, ca. 1000-300 f.Kr. Stockholm studies in Archaeology 71. (Doktorsavhandling.) Stockholms universitet, Stockholm.

Schiffer, M. (1987). Formation processes of the archaeological record. Salt Lake City: University of Utah Press.

Sigvallius, B. (1994). Funeral pyres. Iron Age cremations in North Spånga. (Doktorsavhandling.) Stockholms universitet, Stockholm 
Sjölin, M. (2010). Röjningsrösen och gravar på Stora Farstorp. Arkeologisk utredning. Inför ställverksbygget i samband med utbyggnad av Sydvästlänken. Stora Farstorp, fastigheterna Kramsäng 1:4 och Ryssby 2:11. RAÄ 280, Barkeryds socken, Nässjö kommun, Småland, Jönköpings län. Dnr 421-2425-2010. RAÄ, UV Öst. Rapport 2010:39. Linköping: RAÄ.

Sjölin, M. (2011). Arkeologisk förundersökning. Fastigheten Kramsäng 1:4. Inför byggnad av kraftstation. Boplatslämningar kring stensättningarna RAÄ 288, 289, 296 Barkeryds socken, Nässjö kommun, Småland. RAÄ. Rapport UV Öst 2011:103. Linköping, RAÄ.

Sjölin, M. (2013a). Farstorp - ett röjningsröseområde med gravar. Arkeologisk förundersökning med anledning av utbyggnad av Sydvästlänken. Småland, Nässjö kommun, Barkeryds socken, Kramsäng 1:2 och 1:4, RAÄ 284 och 295. Dnr 422-02821-2012. RAÄ. UV Rapport 2013:47. Stockholm, RAÄ.

Sjölin. M. (2013b). Romersk järnålder vid Stora Farstorp. Arkeologisk undersökning. Småland, Nässjö kommun, Barkeryds socken, Kramsäng 1:4, RAÄ 288, 289, 296,307, 308. Dnr 423-03007-2011. RAÄ. UV Rapport 2013:89. Stockholm, RAÄ.

Sjölin, M. (2015). Krogarängen - ett romartida gravfält. Arkeologisk undersökning. Östergötland, Vadsten kommun, Vadstena och Sankt Per socken, Kvissberg 2:5 och 2:6, Del av RA ̈̈ 11 i Vadstena socken, Del av RAÄ 36 i Sankt Per socken, RAÄ 67, 68 och 74 i Vadstena socken. Dnr 423-01493-2010. SHMM. Arkeologiska uppdragsverksamheten. Rapport 2015:17. Stockholm, Statens historiska museer.

Skoglund, P. (2005). Vardagens landskap. Lokala perspektiv på bronsålderns materiella kultur. Stockholm: Almqvist \& Wiksell International.

Skoglund, P. (2006). Inlandsarkeologi. Vetenskapligt program för uppdragsarkeologin vid Smålands museum. Växjö: Smålands museum.

Steinsland, G. 2007. Fornnordisk religion. Stockholm: Natur och kultur.
Stilborg, O. (2008). Förhistorisk järnhantering i Östergötland - det metallurgiska och keramiska källmaterialet, I E. Räf (Red.), Varifrån kom järnet? Förhistorisk järnframställning $i$ Östergötland (s. 81-113). Linköping: Östergötlands länsmuseum.

Stilborg, O. (2014). Den aktivitetskänsliga keramiken. Keramiska fynd från RAÄ 295, Barkeryds socken, Jönköpings län. Rapport. SKEA. (Bilaga 11 i Petersson, 2015.)

Stjernquist, B. (1997). The Röekillorna spring. Spring-cults in Scandinavian prehistory. Stockholm: Almqvist \& Wiksell International.

Straume, E. (1984). Fasettslipte glass $i$ nordiske graver fra 4. og 5. århundre e.Kr. Stensil. Oslo universitet, Oslo.

Svanberg, F. 2000. Gravar i röjningsröseområden. De förmodade gravarna inom Hamneda RAÄ 77 och problematiken kring röjningsröseområden och gravar i södra Sverige. I P. Lagerås (Red.), Arkeologi och paleoekologi i sydvästra Småland. Tio artiklar från Hamnedaprojektet (s. 113-133). Stockholm: RAÄ.

Vestbö-Franzén, A. (2004). Råg och rön. Om mat, människor och landskapsförändringar i norra Småland, ca. 1550-1700. (Doktorsavhandling.) Stockholms universitet, Stockholm.

Widgren, M. (Red.) (2003). Röjningsröseområdena på sydsvenska höglandet - arkeologiska, kulturgeografiska och vegetationshistoriska undersökningar. Kulturgeografiska institutionen, Stockholms universitet, Stockholm.

Wigren, S. (1987). Sörmländsk bronsåldersbygd. En studie av tidiga centrumbildningar daterade med termoluminiscens. (Doktorsavhandling.) Stockholms universitet, Stockholm.

Åstrand, J. 2007. Den medeltida gården vid Markaryd. I M. Hansson (Red.), Utmarker, gårdar och människor. Om järnålder och medeltid i sydvästra Småland (s. 55-85). Växjö: Smålands museum.

Åstrand, J. 2012. Gravar och boplats vid Vedeby. Karlskrona 6:24, Stadsträdgården, Vedeby. Karlskrona socken, Karlskrona kommun. Särskild undersökning 2011. Blekinge museum rapport 2011:8/Smålands museum rapport 2012:6. Växjö: Smålands museum. 